\title{
Agrometeorological models for forecasting the qualitative attributes of "Valência" oranges
}

\author{
Victor Brunini Moreto ${ }^{1}$ • Glauco de Souza Rolim ${ }^{1}$ • Bruno Gustavo Zacarin ${ }^{2}$ • \\ Ana Paula Vanin ${ }^{2} \cdot$ Leone Maia de Souza ${ }^{2}$ - Rodrigo Rocha Latado ${ }^{3}$
}

Received: 24 November 2015 / Accepted: 24 August 2016 / Published online: 8 September 2016

(C) Springer-Verlag Wien 2016

\begin{abstract}
Forecasting is the act of predicting unknown future events using available data. Estimating, in contrast, uses data to simulate an actual condition. Brazil is the world's largest producer of oranges, and the state of São Paulo is the largest producer in Brazil. The "Valência" orange is among the most common cultivars in the state. We analyzed the influence of monthly meteorological variables during the growth cycle of Valência oranges grafted onto "Rangpur" lime rootstocks (VACR) for São Paulo, and developed monthly agrometeorological models for forecasting the qualitative attributes of VACR in mature orchard. For fruits per box for all months, the best accuracy was of $0.84 \%$ and the minimum forecast range of 4 months. For the relation between ${ }^{\circ}$ brix and juice acidity (RATIO) the best accuracy was of $0.69 \%$ and the minimum forecast range of 5 months. Minimum, mean and maximum air temperatures, and relative evapotranspiration were the most important variables in the models.
\end{abstract}

Keywords Agrometeorology · Crop model · Early prevision · Prediction · Citrus sinensis L. Osbeck

Victor Brunini Moreto

victor.moreto@hotmail.com

Rodrigo Rocha Latado

rodrigo@centrodecitricultura.br

1 Department of Exact Science, Faculdade de Ciências Agrárias e Veterinárias, University of São Paulo State (UNESP), Jaboticabal, São Paulo, Brazil

2 Fisher Group S. A, Matão, São Paulo, Brazil

3 Citrus Center 'Sylvio Moreira, Cordeirópolis, São Paulo, Brazil

\section{Introduction}

The citrus sector has a broad social and economic importance in Brazil. The country is the largest exporter of concentrated orange juice in the world (Santos et al. 2013), and the state of São Paulo produces the most high-quality oranges, mainly for juice. For every five cups of orange juice consumed in the world, at least three are produced in Brazil (Neves et al. 2012). Economics, plant-health problems, and lower juice consummation around the world (Neves et al. 2012) have forced the citrus industry to find new alternatives for ensuring its future. Climate is the major factor influencing the yield and quality of oranges (Paulino et al. 2007). Anticipating fruit quality before the harvest is fundamental for producers to plan their crops (Ruslan et al. 2012). This planning begins in April for the state of São Paulo, but new techniques are required to help producers and the agricultural industry to plan their activities. The "Valência" orange is a highly regarded sweet orange due to its high yield and appropriate fruit size (Pio et al. 2005). From the industrial point of view, these oranges represent one of the pillars of agroindustry around the world due to the high quality of their juice for processing, storage, and transport (Coelho 2002).

Agrometeorological models for forecasting crop yield and quality offer an option for understanding the regional climatic conditions and requirements of orchards. These models are useful tools for planning the activities in an area and can also identify the meteorological variables that are most influential during the various phenological phases of the crop cycle.

Several agrometeorological models have been developed for estimating yield and quality for perennial and annual crops using simple or multiple linear regressions. The major difficulty in modeling is to select independent variables that provide the most information and best results. Many methods are available for this selection: forward selection, backward elimination, 
stepwise selection, leaps-and-bounds regression, orthogonal descriptors, genetic algorithms, genetic populations, choosing operators, and fitness of evaluation (Xu and Zhang 2001).

Salvo et al. (2012) developed regression models as a function of climatic variables for estimating the yield of blueberries in Chile. Pedro Junior et al. (2014) produced estimation models for soluble solids and titratable acidity of grapes for the state of São Paulo, also using regressions, as a function of growing degree days. Similarly, Nyamdorj et al. (2014) developed empirical models to estimate the responses of yield and quality of blueberries in eastern Australia as a function of climatic variables.

Models have also been developed for estimating the yield and quality of oranges. Camargo et al. (1999) developed an agrometeorological model to estimate the yield of Valência oranges as a function of a hydric factor and identified flowering and initial fruit set as the phases most sensitive to water deficit. Volpe et al. (2002) concluded that air temperature, represented by growing degree days, was the most influential variable for the maturation rate of Valência and "Natal" oranges from the first flowering and used this variable for developing quadratic regression models. Paulino et al. (2007) have used adjusted multiple linear regressions to describe the correlation between the number of fruits per plant and meteorological variables at different phases of the Valência orange cycle. Air temperature and water deficit were the most important variables at bud formation, onset of flowering and vegetative dormancy for orchards 6-10 years of age. Moreto et al. (2015) reported similar results with estimation models using multiple linear regressions as functions only of water deficit. Water restrictions during the developmental (pre-production) year had a large effect on the yield of Valência oranges, but deficits at maturity (production year) strongly affected the quality of the fruit.

Few models, however, have been developed for forecasting yield. One example, though, used linear regression to predict maize yield at Jilin, China (Matsumura et al. 2014). Yield can be forecasted in different ways. Satellites can use the normalized difference vegetation index and general circulation models to associate yield with weather forecasts. Kogan et al. (2013) achieved a range of 2-3 months for predicting wheat yield in the Ukraine. Temporal series analysis (Box et al. 2008) and using El Niño and La Niña standards are other methods. For example, Hansen et al. (2004) forecasted wheat yield for the pre-planting period in northeastern Australia. Statistical models can also use mean and historical climatic data. We developed monthly agrometeorological models to forecast qualitative attributes of Valência oranges (Citrus sinensis, L. Osbeck) grafted onto "Rangpur" lime (Citrus limonia, Osbeck) rootstocks (VACR) for the four important producing regions of Bauru, Bebedouro, Limeira, and Matão in São Paulo and to identify the meteorological variables with the most influence on VACR quality.

\section{Material and methods}

Local daily climatic data (Table 1) were obtained from automated meteorological stations. Data for precipitation $(P)$ and minimum, mean and maximum air temperatures were organized on monthly scales for 2000-2013 for calculating potential evapotranspiration (PET) using the equation by Camargo (1971) (Eqs. 1, 2, 3, 4, and 5). The models were calibrated with data for 2001-2009 and tested (validation) with data for 2010-2013.

$\mathrm{PET}=0.01 \times Q_{O} \times T \times \mathrm{ND}$

$Q_{O}=37.6 \times \mathrm{DR} \times\left[\left(\frac{\pi}{180}\right) \times h n \times \sin \Phi \times \delta+\cos \Phi \times \cos \delta \times \sin h n\right]$

$\mathrm{DR}=1+0.033 \times \cos \left(\frac{360 \times \mathrm{JD}}{365}\right)$

$\delta=23.45 \times \sin \left[\left(\frac{360}{365}\right) \times(J D-80)\right]$

$h n=\operatorname{ARCCOS}[-\tan \Phi \times \tan \delta]$

where $Q_{o}$ is the daily solar irradiance at the top of the atmosphere $\left(\mathrm{MJ} \mathrm{m}^{-2}\right.$ day $\left.^{-1}\right), \mathrm{DR}$ is the relative distance from earth to sun (au, astronomic units), $h n$ is the hour angle at sunrise $\left(^{\circ}\right), \Phi$ is the latitude $\left(^{\circ}\right), \delta$ : is the solar declination $\left(^{\circ}\right), \mathrm{JD}$ is the Julian day, $T$ is the mean air temperature $\left({ }^{\circ} \mathrm{C}\right)$, and $N D$ is the number of days of the period.

Monthly information for water deficit (DEF), water excess (EXC), soil-water storage (STO), and actual evapotranspiration (AET) were generated by the Thornthwaite and Mather (1955) water-balance method with an available water capacity of $100 \mathrm{~mm}$. Minimum (Tmin), mean (T) and maximum (Tmax) air temperatures, precipitation $(P)$, relative evapotranspiration $(\mathrm{RET}=\mathrm{AET} / \mathrm{PET}), \mathrm{DEF}, \mathrm{EXC}$, and STO were used as independent variables for developing models with multiple linear regressions (Eq.6). Only variables from the developmental year (primary phenological year) (Fig. 1) were used for forecasting, totaling 73 independent variables $(X \mathrm{~s})$ pre-selected as the most important for each region.

Table 1 Local and climatic descriptions of the regions of production

\begin{tabular}{lllll}
\hline Locals & $\begin{array}{l}\text { Latitude } \\
(\mathrm{S})\end{array}$ & $\begin{array}{l}\text { Longitude } \\
(\mathrm{W})\end{array}$ & $\begin{array}{l}\text { Altitude } \\
(\mathrm{m})\end{array}$ & $\begin{array}{l}\text { Thornthwaite (1948) } \\
\text { climatic classification }\end{array}$ \\
\hline Bauru & $22^{\circ} 17^{\prime} 29^{\prime \prime}$ & $49^{\circ} 33^{\prime} 10^{\prime \prime}$ & 561 & $\mathrm{C}_{2} \mathrm{sB}_{4}^{\prime} \mathrm{a}$ \\
Bebedouro & $20^{\circ} 56^{\prime} 58^{\prime \prime}$ & $48^{\circ} 28^{\prime} 45^{\prime \prime}$ & 573 & $\mathrm{C}_{2} \mathrm{dA}^{\prime} \mathrm{a}$ \\
Limeira & $22^{\circ} 33^{\prime} 53^{\prime \prime}$ & $47^{\circ} 24^{\prime} 06^{\prime \prime}$ & 588 & $\mathrm{~B}_{1} \mathrm{rB}_{3}^{\prime} \mathrm{a}$ \\
Matão & $21^{\circ} 36^{\prime} 12^{\prime \prime}$ & $48^{\circ} 21^{\prime} 57^{\prime \prime}$ & 585 & $\mathrm{~B}_{1} \mathrm{rB}_{4}^{\prime} \mathrm{a}$ \\
\hline
\end{tabular}




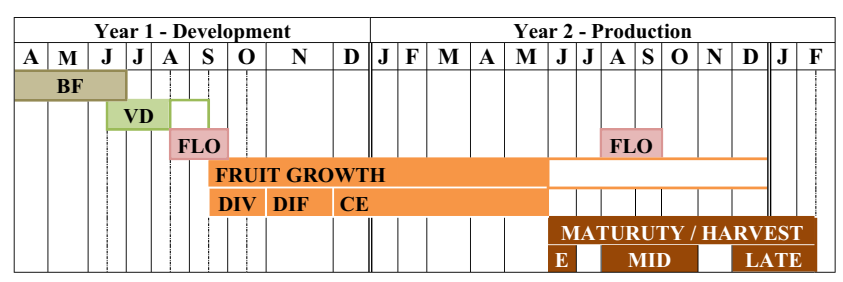

Fig. 1 Mean phenology of Valência oranges grafted onto Rangpur lime rootstocks in the state of São Paulo. $B D$ bud formation, $V D$ vegetative dormancy, $F L O$ flowering, $D I V$ cell division, $D I F$ cell differentiation, $C E$ cell expansion, $E$ early crop harvest of Valência oranges, $M I D$ mid-crop harvest of Valência oranges, LATE late crop harvest of Valência oranges

$Y=a \times X_{1}+b \times X_{2}+c \times X_{3}+\cdots+\mathrm{LC}$

where $Y$ is the fruits per box, as BRIX, kilograms of soluble solids, ratio, acidity, fruit weight, and juice percentage; $a, b, c$, $\ldots$ are the angular coefficients; $X_{1}, X_{2}, X_{3} \ldots$ are the selected meteorological variables; and $L C$ is the linear coefficient.

Monthly data for RATIO (Eq. 7), fruit sugar content (BRIX) measured by refractometer, kilograms of soluble solids per box (KGSS) (Eq. 8), citric acid percentage (ACIDITY), juice percentage (\%JUICE) (Eq. 9), fruits per box (FRBOX), and fruit weight (WFRUIT) of VACR oranges were obtained from local producers. For better application in the models, these data were organized as means of the two flowerings of mature orchards (more than 6 years). Orange trees usually flower twice per 2-year cycle, induced by thermal and/or water stresses, but more flowerings can occur if climatic stresses are out of season.

$$
\begin{aligned}
& \text { RATIO }={ }^{\circ} \text { BRIX } \times \mathrm{ACIDITY}^{-1} \\
& \mathrm{KGSS}=\mathrm{JC} \times{ }^{\circ} \mathrm{BRIX} \times 40.8 \times 10^{-4} \\
& \% \mathrm{JUICE}=\mathrm{WJUICE} \times \mathrm{WFRUIT}^{-1} \times 100
\end{aligned}
$$

where $J C$ is the juice content (L), WJUICE is the juice weight $(\mathrm{kg})$, and 40.8 is the box weight $(\mathrm{kg})$.

The largest problem in multiple linear regressions is to select the best combination of independent variables to be combined for generate significant models. Any numeric interactive method, as the stepwise selection, has stabilization problems in local errors due to poor initial combinations. An option is to test all possible combinations (APC) when the number of independent variables is relatively small (Walpole et al. 2012).

We used the APC method for testing models with 1-3 independent variables from the developmental year on a monthly scale, producing 64,897 possible equations for each dependent variable (RATIO, BRIX, KGSS, ACIDITY, $\%$ JUICE, FRBOX, and WFRUIT), totaling 519,176 tested equations for each month. A routine in visual basics applications was used to develop these equations. The criteria applied for selecting the variables were the significance of the coefficients $(t<0.05)$ and regressions $(F<0.05)$, a low mean absolute percentage error (MAPE) and a high adjusted coefficient of determination ( $R^{2}$ adj) (Eqs. 10 and 11).

$\operatorname{MAPE}(\%)=\frac{\sum_{i=1}^{N}\left(\left|\frac{Y \text { est }_{i}-Y \text { obs }_{i}}{Y \text { obs }_{i}}\right| \times 100\right)}{N}$

$R^{2}$ adjusted $=\left[1-\frac{\left(1-R^{2}\right) \times(N-1)}{N-k-1}\right]$

where $Y_{\text {est }}$ is the estimated quality attributes at year $i, \operatorname{Yobs}_{i}$ is the observed quality attributes at year $i, N$ is the data number, and $k$ is the number of independent variables at the regression.

The multicollinearity between the monthly independent variables ( $T \min , T, T \max , P$, RET, DEF, EXC, and STO) were removed. Gujarati and Porter (2011) suggested that multicollinearity was not a problem for models that only estimate, but multicollinearity can cause bias in the analysis of angular coefficients, such as in our study. The analysis of angular coefficients allows the identification of the meteorological elements with the most influence on forecasting yield and quality and the times at which they are important.

\section{Results and discussion}

\subsection{Local climatic analysis}

The Bauru (BAU), Bebedouro (BEB), Limeira (LIM), and Matão (MAT) regions have similar annual climatic characteristics but have some seasonal differences that affect yield and quality and that lead to some different responses of Valência orange crops (Fig. 2).

These regions can be divided into two groups based on temperature (Fig. 2): $G_{\mathrm{T}} 1$ represented by BEB and MAT with $T$ between 22 and $25{ }^{\circ} \mathrm{C}$ and $G_{\mathrm{T}} 2$ represented by LIM and BAU with $T$ between 20 and $23{ }^{\circ} \mathrm{C}$ (Table 2). The lowest $T \mathrm{~s}$ occurred in May, June, and July, the months of the phenological phases that precede flowering, such as bud formation and vegetative dormancy. Mean $P$ was low in winter in all regions (Fig. 2), extending into August (beginning of flowering). The northern producing regions of the state of São Paulo had similar conditions (Sentelhas 2005). The evapotranspiration demand was fulfilled between November and March (Fig. 2) for all regions (RET $>0.9$ ). The largest restriction of evapotranspiration occurred in August, when AET reached $40 \%$ of PET in BEB. BAU was the only region with an excess of water during the dry period (Fig. 2). The regions could thus also be divided into two groups based on their water-balance components (DEF, STO, and EXC): $G_{\mathrm{WB}} 1$ (BAU) and $G_{\mathrm{WB}} 2$ (LIM, MAT, and BEB) (Table 2). The division for RET was the same as for water balance. The dry period is important for the flowering of orange crops and thus for quality and uniformity. Lower water availability and temperatures are major inducers 
a

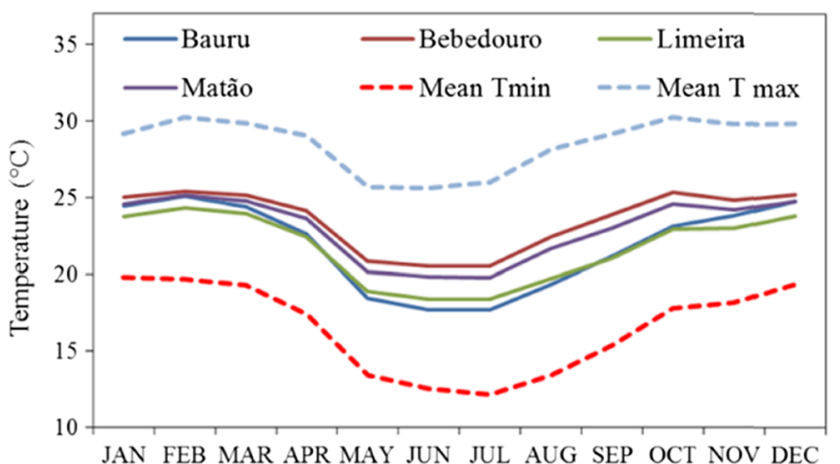

c

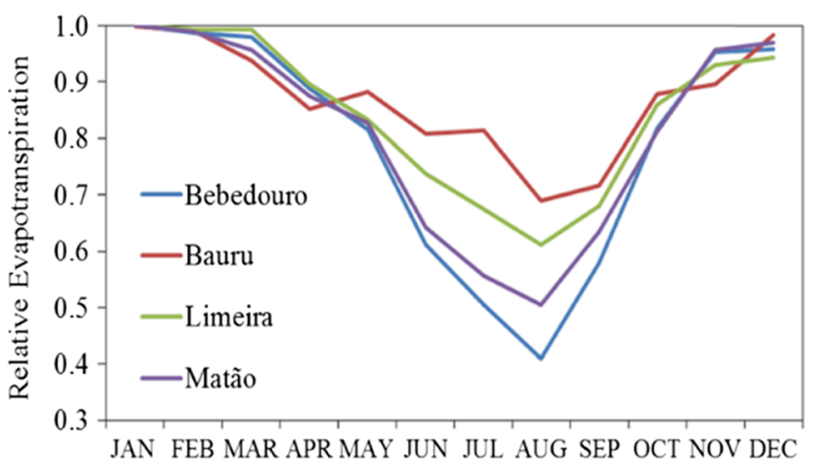

Fig. 2 Climatic characteristics of the regions for 2000-2013. a Monthly mean air temperature $\left({ }^{\circ} \mathrm{C}\right)$, b precipitation and soil-water storage $(\mathrm{mm})$, c relative evapotranspiration, and $\mathbf{d}$ water deficit (DEF) and excess (EXC)

of flowering during this phase of the crop cycle (Castro et al. 2001).

The most important variables for inducing flowering were DEF in BEB and MAT, belonging to groups $G_{\mathrm{T}} 1$ and $G_{\mathrm{WB}} 2$, T in LIM, belonging to groups $G_{\mathrm{T}} 2$ and $G_{\mathrm{WB}} 2$, and $\mathrm{DEF}$ and $T$ in BAU, belonging to groups $G_{\mathrm{T}} 2$ and $G_{\mathrm{WB}} 1$ (Ribeiro et al. 2006).

\subsection{Model classification}

To develop accurate agrometeorological models that could forecast the qualitative attributes of VACR with maximum range we

Table 2 Similarity groups of the water-balance components of the regions

Similarity groups

\begin{tabular}{llll}
\hline \multicolumn{2}{l}{ Mean air temperature } & \multicolumn{2}{l}{ Water Balance (STO, DEF, EXC, and RET) } \\
$G_{\mathrm{T}} 1$ & Bebedouro & $G_{\mathrm{WB}} 1$ & Bauru \\
$\left(22-25^{\circ} \mathrm{C}\right)$ & Matão & (EXC until July) & \\
$G_{\mathrm{T}} 2$ & Limeira & $G_{\mathrm{WB}} 2$ & Bebedouro \\
$\left(20-23^{\circ} \mathrm{C}\right)$ & Bauru & $(\mathrm{EXC}$ until April) & Limeira \\
& & & Matão \\
\hline
\end{tabular}

$S T O$ soil-water storage, $D E F$ water deficit, $E X C$ water excess, $R E T$ relative evapotranspiration

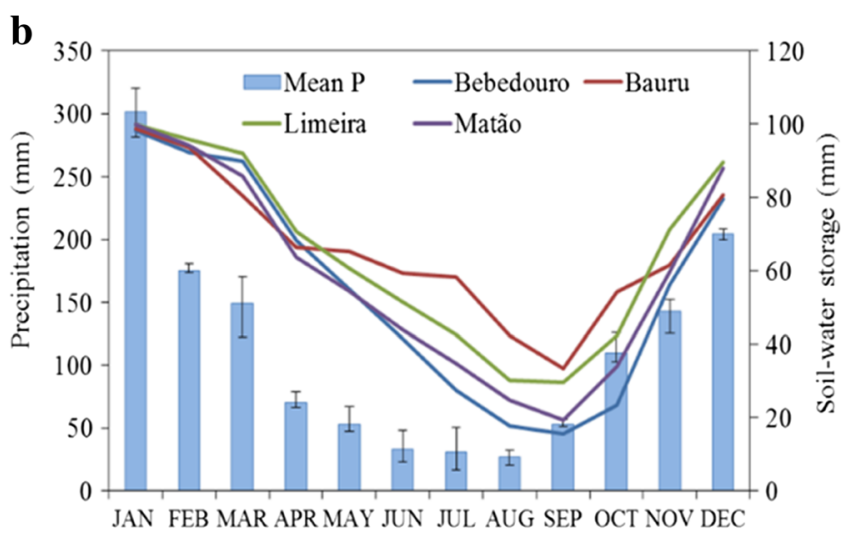

d

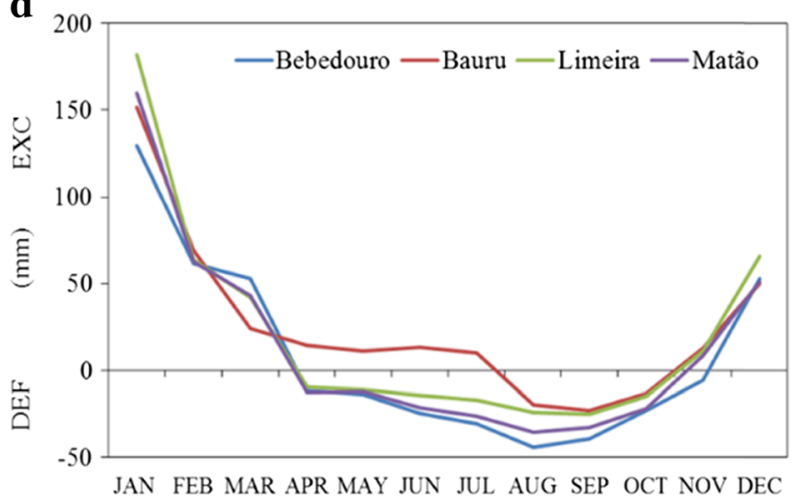

(mm). The water-balance components were estimated by the method of Thornthwaite and Mather (1955), with an available water capacity of $100 \mathrm{~mm}$

tested all possible combinations of 1-3 of the monthly climatic variables $(64,897$ combinations) from the developmental year (primary phenological year). The combinations that showed multicollinearity $(21,380)$ were rejected, and the remaining combinations $(43,517)$ represented the best possible monthly models for forecasting the qualitative attributes of VACR (Fig. 3).

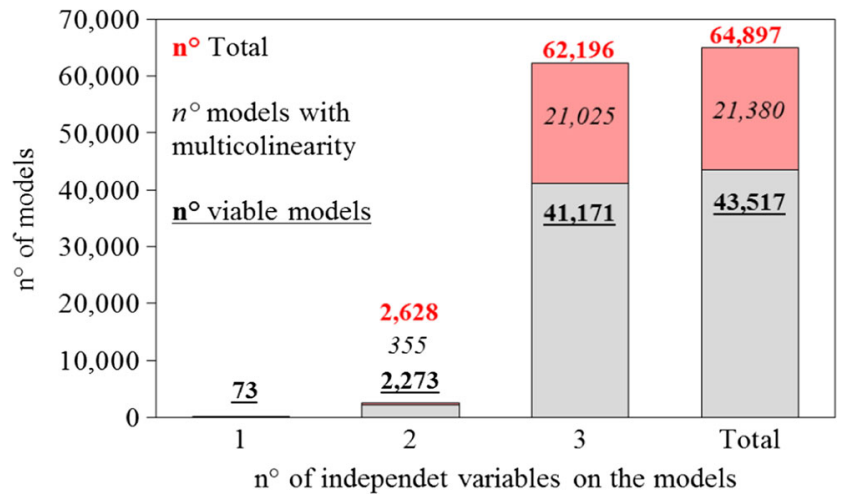

Fig. 3 Number of generated and tested equations for multicollinearity analyses for developing the agrometeorological models for forecasting the yield and quality of Valência oranges grafted onto Rangpur lime rootstocks as a function of the monthly climatic variables for the developmental year. $\boldsymbol{n}^{\circ}$ number of models generated, $n^{\circ}$ number of models with multicollinearity between the independent variables above 0.7 , and $\underline{n^{\circ}}$ number of viable forecasting models 
The APC method was efficient because $P$ decreased as $R^{2}$ adj increased, and the MAPE consequently decreased (Fig. 4). We used these criteria for identifying the best models for forecasting the qualitative attributes of VACR.

\subsection{Sensitivity analysis}

The sensitivities of the angular coefficients of the climatic variables for the developmental year (Figs. 5 and 6) were analyzed to identify those with more influence on the RATIO and FRBOX of VACR in the regions. The juiceprocessing industries begin their planning in April, so we used this month for the sensitivity analyses. Sensitivity analyses are important to evaluate either crop-modeling approaches or the application of modeling solutions exploring combinations between local and climate conditions (Confalonieri et al. 2010).

The sensitivity analyses identified the most influential variables in the ten most accurate models for forecasting

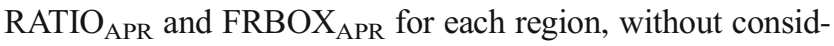
ering the range. The RATIO ${ }_{\text {APR }}$ models had MAPEs of 2.58$4.17 \%$ for BAU, $1.86-3.52 \%$ for BEB, $2.02-3.97 \%$ for LIM, and 4.86-7.63\% for MAT. The accuracies of the FRBOX $_{\text {APR }}$ models were $1.75-2.38 \%$ for BAU, 5.15$6.83 \%$ for BEB, $1.29-3.06 \%$ for LIM, and $4.06-11.43 \%$ for MAT.

The most important general climatic variables for forecasting RATIO $_{\mathrm{APR}}$ for all regions were $T_{\mathrm{MAY}}, T_{\mathrm{JUL}}, T_{\mathrm{NOV}}$, $T \max _{\mathrm{MAR}}, T \max _{\mathrm{APR}}, T \max _{\mathrm{JUN}}, T \max _{\mathrm{DEC}}, T \min _{\mathrm{MAY}}$, $\mathrm{RET}_{\mathrm{APR}}, \mathrm{RET}_{\mathrm{MAY}}, \mathrm{RET}_{\mathrm{JUN}}$, and RET $\mathrm{REP}_{\mathrm{S}}$.

All coefficients were positive for LIM, indicating that the climatic variables for this region were positively correlated with $\mathrm{RATIO}_{\mathrm{APR}}$. Tmax MAR $_{\mathrm{MA}}$ and $T_{\mathrm{MAY}}$ were the most important variables in the best RATIO $_{\text {APR }}$ forecast models for BEB and MAT, which have similar climatic conditions, especially temperature (Ribeiro et al. 2006). These variables had mostly negative coefficients, indicating negative correlations. RET was the most influential positively correlated variable in BAU, but $T \max _{\text {MAR }}$ was also important in the models but was negatively correlated with RATIO.
The angular coefficients of the $\mathrm{FRBOX}_{\mathrm{APR}}$ forecasting models indicated that the most important climatic variables for all regions were $T_{\mathrm{JAN}}, T_{\mathrm{APR}}, T_{\mathrm{JUL}}, T_{\mathrm{NOV}}, T \max _{\mathrm{APR}}$,

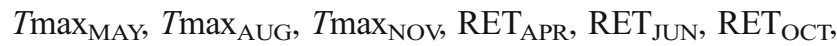
$\mathrm{STO}_{\mathrm{MAY}}, \mathrm{STO}_{\mathrm{JUN}}, \mathrm{DEF}_{\mathrm{JUL}}$, and $\mathrm{EXC}_{\mathrm{DEC}}$. These variables can be positively or negatively correlated with VACR yield.

The variables of water availability (STO, DEF, EXC, $P$, and RET) in BAU were more influential in the models. Their coefficients were negatively correlated with FRBOX. RET was the most influential variable in the BEB and LIM models, with positive and negative correlations, respectively. The variables of temperature, mainly $T_{\mathrm{JAN}}$ and $T \max _{\mathrm{MAY}}$, were most influential for MAT, with positive coefficients and a positive correlation with FRBOX.

\subsection{Agrometeorological forecasting models}

Agrometeorological models have demonstrated that using climatic variables for forecasting crop yields reduces the uncertainties related to the production, making agricultural activities more reliable (Hammer et al. 2000). These forecasts, when accurate, provides important information about soil and/or water management problems in agricultural areas, capturing the complexity and uncertainties and serving as a platform for making decisions and creation of farm policies (Cabrera et al. 2006; Carmona et al. 2013). The agrometeorological models for forecasting RATIO, BRIX, KGSS, ACIDITY, \%JUICE, FRBOX, and WFRUIT of VACR developed in this study were mostly highly accurate in the calibration and testing steps.

All models analyzed were significant and accurate at calibration $(P \leq 0.050$ and MAPE $\leq 10.46 \%)$. The models with the lowest $P$ and MAPE (high accuracy) were WFRUIT $_{\text {NOV }}$ and

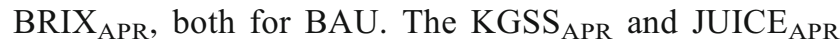
models for $\mathrm{BEB}$ had minimum ranges of 3 months. The WFRUIT $_{\text {OCT }}$ model for BEB had the longest range of all models, a forecast of approximately 1 year. Relationships between crop and climatic variables are more statistical than physiological the longer the forecast. Longer ranges, such as
Fig. 4 Example of the agrometeorological model classification for Bebedouro, following the criteria of accuracy (low MAPE), precision (high $R^{2}$ adj) and reliability $(P<0.05)$

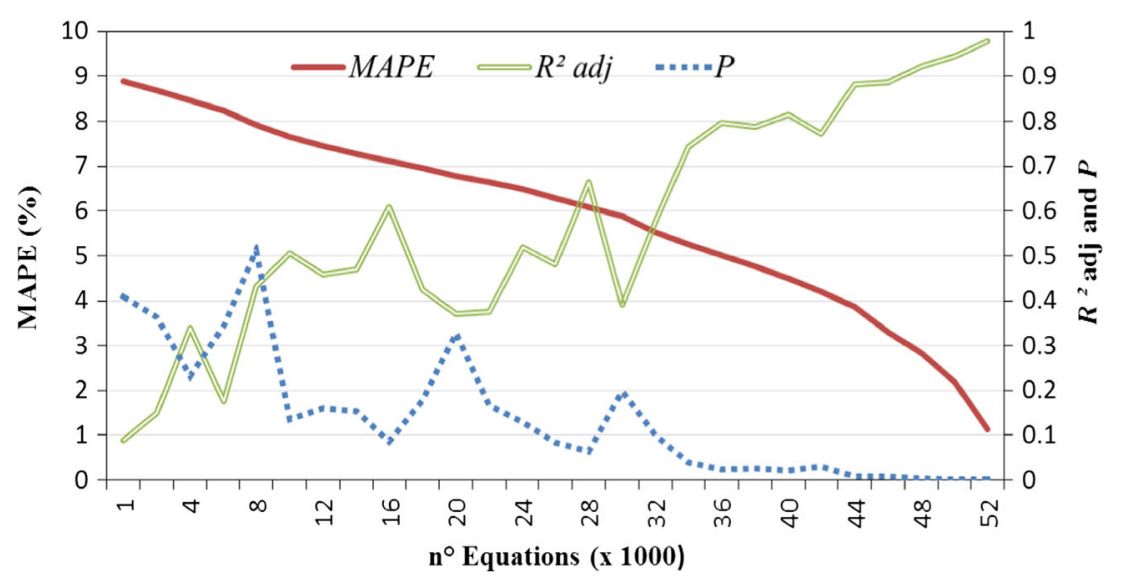



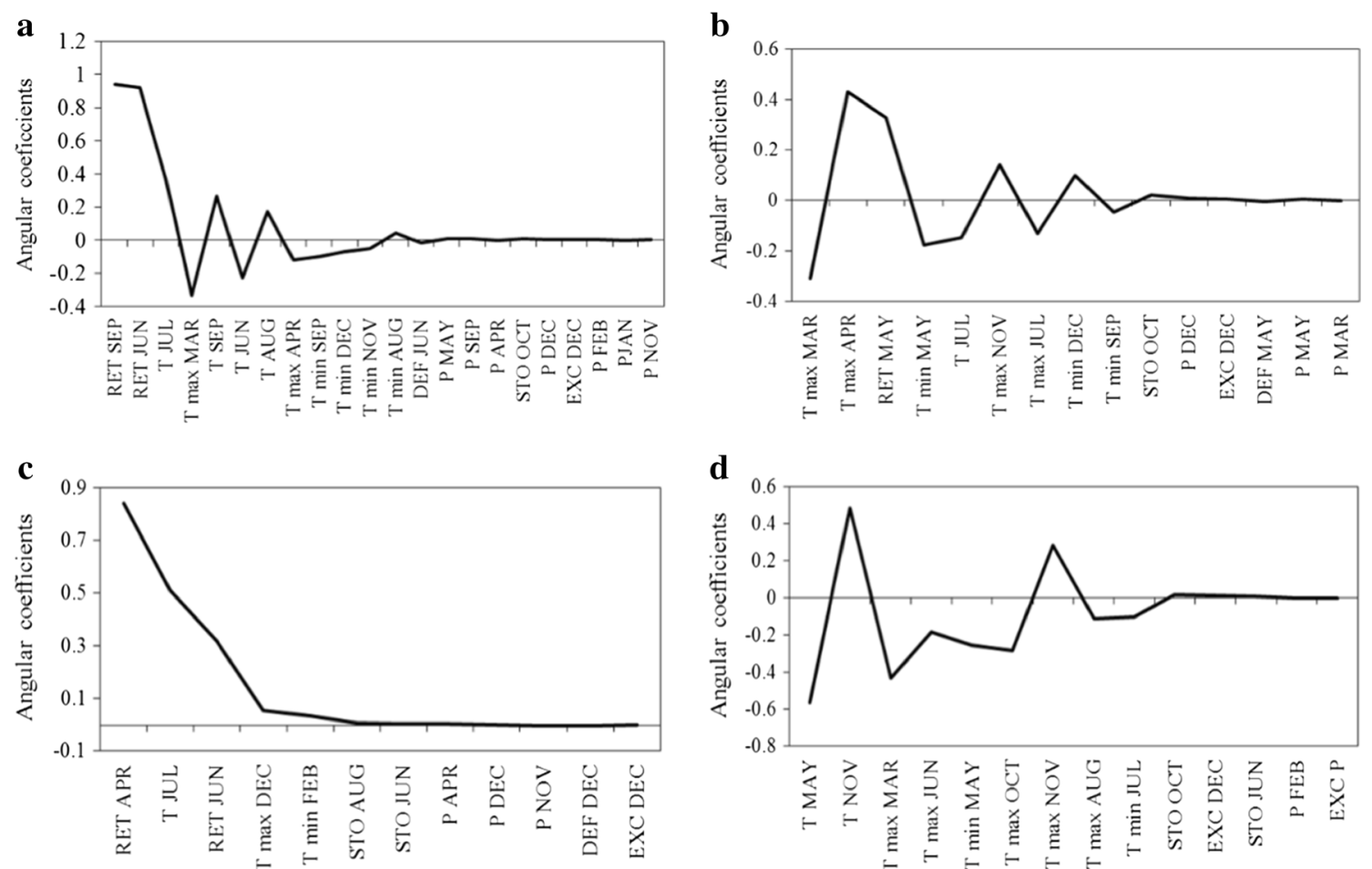

Fig. 5 Sensitivity analysis of the mean angular coefficients from the ten most accurate models for forecasting RATIO for April of Valência oranges grafted onto Rangpur lime rootstocks. a Bauru. b Bebedouro. c Limeira. d Matão

that of the WFRUIT $_{\mathrm{OCT}}$ model for BEB, indicate that a relationship is more statistical or of engineering.

The models for forecasting RATIO for all regions and months were accurate at testing, with a minimum MAPE of $0.69 \%$ for August in BAU and a maximum of $7.67 \%$ for May
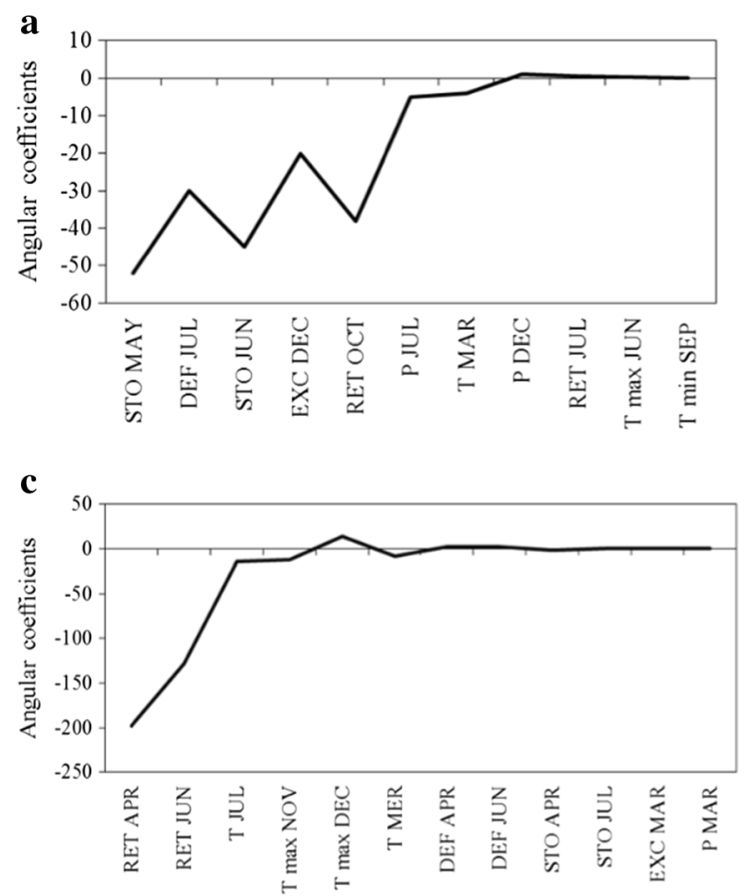

in LIM (Table 3). The minimum range (5 months) for forecasting RATIO was for BEB, LIM, and MAT. The maturity index (RATIO) is the relationship between BRIX and ACIDITY, two major components for the citrus industries. RATIO has a direct impact on the price and quality of juice

b
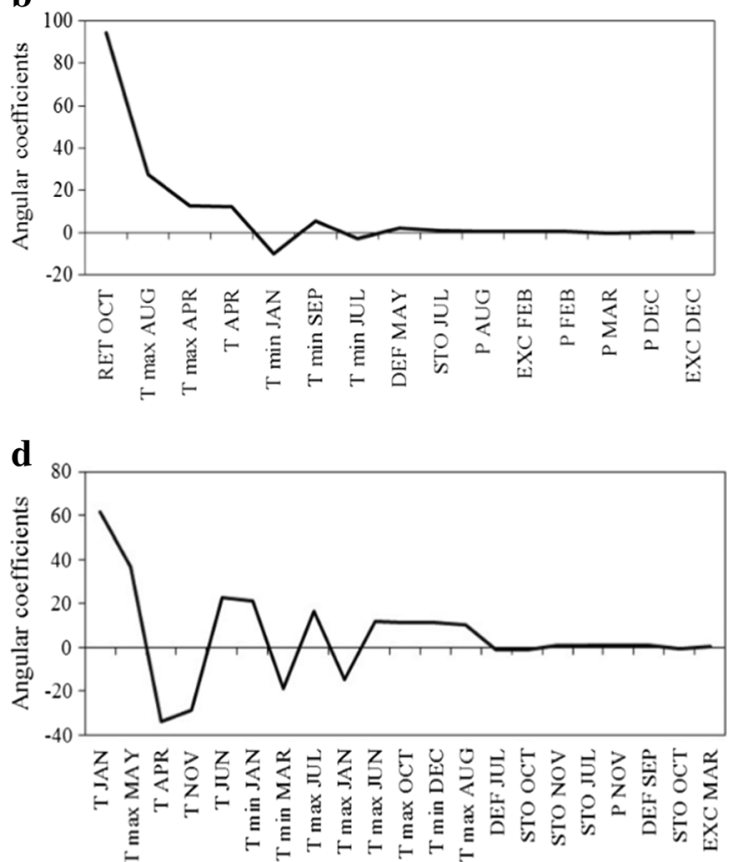

Fig. 6 Sensitivity analysis of the mean angular coefficients from the ten most accurate models for forecasting FRBOX for April of Valência oranges grafted onto Rangpur lime rootstocks. a Bauru. b Bebedouro. c Limeira. d Matão 
Table 3 Monthly agrometeorological models for forecasting RATIO for the state of São Paulo

\begin{tabular}{|c|c|c|c|c|c|c|}
\hline \multirow[t]{2}{*}{ Ratio $(R)$} & & \multirow[t]{2}{*}{$P$ value } & \multicolumn{2}{|l|}{ Calibration } & \multicolumn{2}{|l|}{ Testing } \\
\hline & & & MAPE (\%) & $R^{2}$ adj & MAPE (\%) & $R^{2}$ adj \\
\hline \multicolumn{7}{|l|}{ April } \\
\hline BAU & $R=-0.235 T_{\mathrm{JUN}}+0.043 T \mathrm{~min}_{\mathrm{AUG}}-0.10 T \mathrm{~min}_{\mathrm{SEP}}+7.99$ & 0.036 & 2.64 & 0.85 & 2.58 & 0.98 \\
\hline BEB & $R=-0.612 \operatorname{Tmax}_{\mathrm{FEB}}+0.428 \mathrm{Tmax}_{\mathrm{APR}}+0.023 \mathrm{STO}_{\mathrm{OCT}}+10.081$ & 0.006 & 2.98 & 0.90 & 3.50 & 0.82 \\
\hline LIM & $R=0.509 T_{\mathrm{JUL}}-0.002 \mathrm{DEF}_{\mathrm{SEP}}+0.006 \mathrm{STO}_{\mathrm{AUG}}-5.849$ & 0.004 & 2.67 & 0.87 & 3.90 & 0.63 \\
\hline MAT & $R=-0.581 T_{\mathrm{MAY}}-0.102 T \mathrm{~min}_{\mathrm{JUL}}-0.286 \mathrm{Tmax}_{\mathrm{OCT}}+26.306$ & 0.045 & 8.38 & 0.64 & 6.36 & 0.56 \\
\hline \multicolumn{7}{|l|}{ May } \\
\hline BAU & $R=0.58 T_{\mathrm{FEB}}-0.255 T \mathrm{~min}_{\mathrm{SEP}}-0.072 \mathrm{DEF}_{\mathrm{JUL}}-7.342$ & 0.030 & 4.87 & 0.86 & 3.57 & 0.93 \\
\hline BEB & $R=-0.575 T_{\mathrm{APR}}+0.046 P_{\mathrm{JUL}}-0.02 \mathrm{STO}_{\mathrm{MAY}}+19.252$ & 0.001 & 1.85 & 0.97 & 5.50 & 0.83 \\
\hline LIM & $R=-0.207 T \min _{\mathrm{JUN}}-0.269 \operatorname{Tmax}_{\mathrm{SEP}}+15.066$ & 0.010 & 4.63 & 0.70 & 13.92 & 0.95 \\
\hline MAT & $R=-0.453 \operatorname{Tmin}_{\mathrm{APR}}-0.45 . T \max _{\mathrm{AUG}}+0.013 \mathrm{STO}_{\mathrm{NOV}}+25.119$ & 0.002 & 3.18 & 0.91 & 5.55 & 0.90 \\
\hline \multicolumn{7}{|l|}{ June } \\
\hline BAU & $R=-0.0081 P_{\mathrm{APR}}+0.011 P_{\mathrm{MAY}}-0.02 \mathrm{DEF}_{\mathrm{JUN}}+5.802$ & 0.030 & 3.06 & 0.85 & 2.40 & 0.96 \\
\hline BEB & $R=-0.381 T_{\mathrm{OCT}}-0.256 T \mathrm{~min}_{\mathrm{JUL}}+0.01 P_{\mathrm{JUL}}+17.759$ & 0.007 & 2.90 & 0.89 & 2.12 & 0.97 \\
\hline LIM & $R=-0.181 T_{m_{1}}{ }_{\mathrm{JUN}}+0.384 \operatorname{Tmax}_{\mathrm{APR}}+0.008 \mathrm{EXC}_{\mathrm{DEZ}}-5.813$ & 0.022 & 3.40 & 0.73 & 6.01 & 0.54 \\
\hline MAT & $R=0.091 T \min _{\mathrm{SEP}}-0.260 T \mathrm{max}_{\mathrm{AUG}}+0.006 \mathrm{EXC}_{\mathrm{DEZ}}+13.224$ & 0.022 & 3.59 & 0.73 & 6.31 & 0.91 \\
\hline \multicolumn{7}{|l|}{ July } \\
\hline BAU & $R=0.688 T_{\mathrm{MAY}}-0.413 T \mathrm{~min}_{\mathrm{JAN}}-0.011 P_{\mathrm{MAR}}+2.825$ & 0.044 & 2.55 & 0.82 & 3.74 & 0.73 \\
\hline BEB & $R=-0.241 T_{\mathrm{JUN}}-0.173 \mathrm{Tmin}_{\mathrm{JUL}}+0.154 T \mathrm{~min}_{\mathrm{SEP}}+12.425$ & 0.003 & 2.19 & 0.93 & 1.52 & 0.84 \\
\hline LIM & $R=-0.477 T_{\mathrm{AUG}}+0.014 P_{\mathrm{SEP}}+0.01 \mathrm{STO}_{\mathrm{OCT}}+15.149$ & 0.024 & 3.02 & 0.72 & 3.32 & 0.70 \\
\hline MAT & $R=-0.841 T_{\mathrm{AUG}}-0.151 \mathrm{Tmin}_{\mathrm{JUL}}+0.01 \mathrm{EXC}_{\mathrm{DEC}}+25.577$ & 0.006 & 2.75 & 0.85 & 5.05 & 0.86 \\
\hline \multicolumn{7}{|l|}{ August } \\
\hline BAU & $R=-0.363 T \max _{\mathrm{JUL}}-0.27 \operatorname{Tmax}_{\mathrm{DEC}}-0.008 \mathrm{DEF}_{\mathrm{OCT}}+28.271$ & 0.001 & 0.46 & 0.99 & 0.69 & 0.99 \\
\hline BEB & $R=-0.699 T_{\mathrm{APR}}-0.271 T \mathrm{~min}_{\mathrm{JUL}}+0.321 T \mathrm{max}_{\mathrm{MAR}}+17.011$ & 0.014 & 1.72 & 0.85 & 3.20 & 0.61 \\
\hline LIM & $R=-0.356 T_{\max }^{\mathrm{AUG}}+0.052 \mathrm{DEF}_{\mathrm{AUG}}+0.04 . \mathrm{STO}_{\mathrm{SEP}}+17.375$ & 0.005 & 2.00 & 0.85 & 3.97 & 0.85 \\
\hline MAT & $R=-0.737 T_{\mathrm{AUG}}-0.009 P_{\mathrm{JAN}}+0.023 P_{\mathrm{NOV}}+24.091$ & 0.002 & 3.26 & 0.90 & 5.82 & 0.89 \\
\hline \multicolumn{7}{|c|}{ September } \\
\hline BAU & $R=0.827 T \max _{\mathrm{MAR}}-0.021 \mathrm{DEF}_{\mathrm{JUN}}+0.012 \mathrm{EXC}_{\mathrm{FEB}}-18.834$ & 0.049 & 2.57 & 0.81 & 3.13 & 0.97 \\
\hline BEB & $R=1.057 T_{\mathrm{JAN}}+1.414 T_{\mathrm{max}_{\mathrm{MAY}}}+0.056 \mathrm{STO}_{\mathrm{JUL}}-60.174$ & 0.008 & 2.60 & 0.88 & 2.13 & 0.99 \\
\hline LIM & $R=-0.413 \mathrm{Tmax}_{\mathrm{AUG}}+0.049 \mathrm{STO}_{\mathrm{SEP}}-4.737 \mathrm{RET}_{\mathrm{AUG}}+24.599$ & 0.002 & 1.86 & 0.90 & 4.83 & 0.72 \\
\hline MAT & $R=-1.22 T_{\mathrm{AUG}}+1.096 \operatorname{Tmax}_{\mathrm{APR}}+0.011 \mathrm{EXC}_{\mathrm{DEC}}+0.435$ & 0.039 & 4.70 & 0.66 & 5.02 & 0.97 \\
\hline \multicolumn{7}{|l|}{ October } \\
\hline BAU & $R=-0.85 T_{\mathrm{NOV}}-0.164 T \max _{\mathrm{APR}}-0.633 T \max _{\mathrm{JUN}}+55.118$ & 0.008 & 1.47 & 0.94 & 2.11 & 0.87 \\
\hline $\mathrm{BEB}$ & $R=-0.293 \operatorname{Tmin}_{\mathrm{JUN}}+709 \operatorname{Tmax}_{\mathrm{MAR}}+1.493 \operatorname{Tmax}_{\mathrm{MAY}}-53.112$ & 0.016 & 2.28 & 0.84 & 3.44 & 0.94 \\
\hline LIM & $R=1.094 T_{\mathrm{FEB}}-0.162 T \min _{\mathrm{FEB}}-0.621 T \max _{\mathrm{OCT}}+9.746$ & 0.002 & 1.24 & 0.90 & 4.04 & 0.65 \\
\hline MAT & $R=-0.939 T_{\mathrm{JUN}}-2.224 T_{\mathrm{AUG}}+0.135 \mathrm{DEF}_{\mathrm{APR}}+77.502$ & 0.007 & 5.36 & 0.83 & 4.44 & 0.90 \\
\hline \multicolumn{7}{|c|}{ November } \\
\hline BAU & $R=-0.621 T \max _{\mathrm{MAY}}-0.777 T \max _{\mathrm{JUL}}+54.301$ & 0.004 & 1.57 & 0.91 & 2.76 & 0.82 \\
\hline BEB & $R=-0.183 T \min _{\mathrm{JUN}}+2.238 T \max _{\mathrm{MAY}}-0.77 T \max _{\mathrm{OCT}}-22.392$ & 0.007 & 1.88 & 0.89 & 5.06 & 0.86 \\
\hline LIM & $R=1.326 T_{\mathrm{JUL}}+0.743 T_{\max _{\mathrm{FEB}}}-0.006 \mathrm{EXC}_{\mathrm{JAN}}-34.118$ & 0.005 & 2.42 & 0.86 & 4.15 & 0.49 \\
\hline MAT & $R=-2.829 T_{\mathrm{AUG}}+0.644 T \max _{\mathrm{FEB}}+0.203 \mathrm{DEF}_{\mathrm{APR}}+52.107$ & 0.016 & 5.44 & 0.77 & 4.00 & 0.97 \\
\hline \multicolumn{7}{|c|}{ December } \\
\hline BAU & $R=1.531 T_{\mathrm{JUN}}-1.411 T \max _{\mathrm{JUN}}+0.679 T_{\max _{\mathrm{DEC}}}+5.002$ & 0.038 & 2.91 & 0.84 & 4.61 & 0.68 \\
\hline $\mathrm{BEB}$ & $R=1.888 T \min _{\mathrm{FEB}}+1.006 \operatorname{Tmax}_{\mathrm{AUG}}-1.276 T \mathrm{max}_{\mathrm{SEP}}-2.408$ & 0.013 & 3.87 & 0.85 & 4.73 & 0.96 \\
\hline LIM & $R=-1.49 T_{\mathrm{AUG}}-0.015 \mathrm{EXC}_{\mathrm{JAN}}+0.038 \mathrm{STO}_{\mathrm{OCT}}+46.046$ & 0.002 & 2.59 & 0.89 & 1.51 & 0.98 \\
\hline MAT & $R=4.805 T_{\mathrm{MAR}}-3.381 T_{\mathrm{MAY}}+0.033 P_{\mathrm{AUG}}-34.467$ & 0.033 & 8.03 & 0.68 & 1.67 & 0.98 \\
\hline
\end{tabular}

The dependent variable is for the production year (year 2). Calibration and testing used monthly data from 2001 to 2009 and 2010-2013, respectively The independent variables are Tmin, $T$, and Tmax, minimum, mean and maximum air temperature $\left({ }^{\circ} \mathrm{C}\right) ; E X C$ and $D E F$ hydric excess and deficit; $S T O$ soil-water storage; $P$ precipitation $(\mathrm{mm})$; and $R E T$ relative evapotranspiration for the developmental year (year 1)

$B A U$ Bauru, BEB Bebedouro, LIM Limeira, MAT Matão, 
(Ruslan et al. 2012). Twas the most influential variable among the agrometeorological models for forecasting RATIO in all regions and months. Its angular coefficient was higher than those of the other variables. Temperature during the first semester (six first months of the year) of the developmental year were most frequent in the models for BAU and BEB, but the temperatures during the second semester were more influential for LIM and MAT.

BAU had the most accurate model of RATIO $_{\text {APR, with a }}$ MAPE in the testing phase of $2.58 \%$, a precision $\left(R^{2}\right.$ adj) of 0.98 , and $P$ of 0.036 . A mean RATIO of 3.32 would thus have a forecasting error of only 0.09 points. $T$ at the end of bud formation and the beginning of vegetative dormancy (July) was the most influential variable in this model. February $T$ max, $T$ at vegetative dormancy (July), and $T$ at bud formation (May) were the most influential variables for BEB, LIM, and MAT, respectively. Temperature had the most effect on RATIO in BEB (Volpe et al. 2002). Mattheis et al. (1999) found that temperature changes during plant development generally impacted flavor and fruit composition.

The models for forecasting KGSS for all regions and months were accurate at the testing stage. The minimum MAPE was $0.50 \%$ for August in LIM, and the maximum was $12.96 \%$ for November in BEB. The minimum range for KGSS was three months for BEB. KGSS is also used as a technological index, expressing quality. A high KGSS indicates good fruit quality (Grizotto et al. 2012). Tmax was most frequent and had high angular coefficients in BAU, BEB, and MAT in the second semester (Table 4). $T$ was the most important variable in the first semester in LIM.

The best $\mathrm{KGSS}_{\mathrm{APR}}$ model was for BAU, with a MAPE of $1.80 \%, R^{2}$ adj $=0.80$ and $P=0.039$ at the testing stage. A mean KGSS of $1.73 \mathrm{~kg}$ of SS per box would thus have a forecasting error of $0.03 \mathrm{~kg}$ of SS per box. Tmax during bud formation (April) was the most influential variable in this model. The models for BEB, LIM, and MAT were satisfactory, with Tmax influential at fruit growth (November) and at bud formation (April) in BEB and LIM, respectively. RET at the beginning of bud formation (April) was the most important variable in the $\mathrm{KGSS}_{\mathrm{APR}}$ model for MAT, with an accuracy of $2.31 \%$, a precision of 0.93 and $P=0.0004$ at testing.

The models for forecasting ACIDITY were accurate for all regions and months at testing. The minimum MAPE was $2.14 \%$ for April in LIM, and the maximum was $17.79 \%$ for November in BEB. The accuracy of the models decreased for forecasts near the end of the production year (end of cycle), because the models used independent variables only for the developmental year, which maximized the ranges. The minimum range for ACIDITY was 4 months for MAT and BEB. ACIDITY, \%JUICE, and KGSS determine the quality of oranges (Uribe-Bustamante et al. 2013).

$T$ and Tmax during the first semester were the most frequent variables in the ACIDITY models (Table 5) in BEB (T),
LIM, and MAT (Tmax). RET during the second semester was the most frequent variable for BAU. $T$ during vegetative dormancy (July) and bud formation (May) were most important

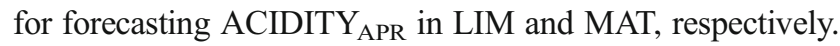
Tmax and RET at bud formation (May and July) were most important in BEB and BAU.

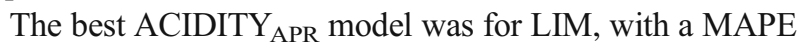
of $2.14 \%, R^{2}$ adj $=0.93$ and $P=0.028$ at testing. A mean ACIDITY of $2.50 \%$ would thus have a forecasting error of $0.053 \%$.

The models for forecasting BRIX were accurate for all regions and months at testing. The minimum MAPE was $0.64 \%$ for June in LIM, and the maximum was $12.10 \%$ for November in BEB. The minimum range of 4 months for BRIX was in BEB and MAT. BRIX represents the sugar content of the juice and is commonly used for blending orange juices from different cultivars to achieve the desired BRIX of a product.

The forecasts of the BRIX agrometeorological models (Table 6) were satisfactory. $T, T$ max, and $T$ min were the most frequent variables among all models and months for BEB, LIM, and MAT, respectively. Temperatures during the first semester were more frequent in the models. Tmax during the second semester was the most frequent variable for BAU.

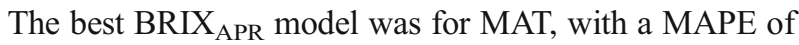
$1.38 \%, R^{2}$ adj $=0.76$ and $P=0.007$ at testing. A mean BRIX of $11.29^{\circ}$ would thus have a forecasting error of $0.16^{\circ}$. Tmin during flowering (August) was the most influential variable in this model, again indicating that this phenological phase is very important for VACR fruit quality.

The models for forecasting \%JUCE were accurate for all regions and months at testing. The minimum MAPE was $0.41 \%$ for October in MAT, and the maximum was $10.20 \%$ for May in BAU. The minimum range was 3 months for BEB. $\%$ JUICE (Table 7) is a variable for both quality and yield, because more fruit will produce more juice. The models developed for \% JUICE were influenced most by temperature in BEB (Tmax), LIM (Tmax), and MAT (T). RET was the most influential variable in BAU. The first-semester variables were more frequent in the \%JUCE forecasting models.

The best \%JUICE $\mathrm{APR}_{\mathrm{AP}}$ model was for LIM, with a MAPE of $1.60 \%, R^{2}$ adj $=0.91$ and $P=0.007$ at testing. A mean $\%$ JUICE of $0.57 \%$ would thus have a forecasting error of $0.00912 \%$. Tmin and Tmax during fruit-cell expansion in December were the most important variables in this model.

Agrometeorological models for forecasting FRBOX developed in this study were strongly dependent on temperature, but at least one model relied on water-balance components (DEF, EXF, and STO) for its forecasts. The FRBOX test models were highly accurate for all months and regions, with a minimum MAPE of $0.84 \%$ for September in BAU and a maximum of $19.52 \%$ for September in MAT. The minimum range for FRBOX was 4 months for BEB and LIM. 
Table 4 Monthly agrometeorological models for forecasting kilograms of soluble solids per box (KGSS) for the state of São Paulo

\begin{tabular}{|c|c|c|c|c|c|c|}
\hline \multicolumn{2}{|c|}{ KGSS (SS) } & \multirow[t]{2}{*}{$P$ value } & \multicolumn{2}{|l|}{ Calibration } & \multicolumn{2}{|l|}{ Testing } \\
\hline & & & MAPE $(\%)$ & $R^{2}$ adj & MAPE (\%) & $R^{2}$ adj \\
\hline \multicolumn{7}{|l|}{ April } \\
\hline BAU & $\mathrm{SS}=-0.077 T \mathrm{max}_{\mathrm{MAR}}-0.002 P_{\mathrm{APR}}-0.001 P_{\mathrm{JUL}}+4.604$ & 0.039 & 2.30 & 0.84 & 1.80 & 0.83 \\
\hline BEB & $\mathrm{SS}=0.083 T \mathrm{max}_{\mathrm{NOV}}+0.002 P_{\mathrm{DEC}}+0.002 \mathrm{DEF}_{\mathrm{JUL}}-1.67$ & 0.006 & 2.38 & 0.90 & 2.66 & 0.82 \\
\hline LIM & $\mathrm{SS}=-0.147 \mathrm{Tmax}_{\mathrm{MAY}}+0.003 P_{\mathrm{AUG}}-0.007 \mathrm{STO}_{\mathrm{APR}}+6.62$ & 0.012 & 2.68 & 0.79 & 3.45 & 0.90 \\
\hline MAT & $\mathrm{SS}=-0.163 T_{\mathrm{APR}}-0.107 \mathrm{Tmax}_{\mathrm{JUN}}-1.23 \mathrm{RET}_{\mathrm{APR}}+9.974$ & 0.001 & 1.37 & 0.95 & 2.31 & 0.93 \\
\hline \multicolumn{7}{|l|}{ May } \\
\hline BAU & $\mathrm{SS}=0.098 T_{\mathrm{AUG}}-0.039 T \min _{\mathrm{JAN}}-0.004 \mathrm{DEF}_{\mathrm{JUN}}+0.883$ & 0.027 & 1.48 & 0.87 & 0.59 & 0.99 \\
\hline BEB & $\mathrm{SS}=-0.031 T \mathrm{~min}_{\mathrm{OCT}}+0.0002 P_{\mathrm{JAN}}+0.003 \mathrm{STO}_{\mathrm{NOV}}+2.31$ & 0.005 & 1.11 & 0.91 & 2.67 & 0.85 \\
\hline LIM & $\mathrm{SS}=-0.004 P_{\mathrm{AUG}}+0.004 P_{\mathrm{SEP}}+0.523 \mathrm{RET}_{\mathrm{MAY}}+1.485$ & 0.031 & 2.13 & 0.69 & 2.29 & 0.98 \\
\hline MAT & $\mathrm{SS}=-0.146 T_{\mathrm{AUG}}+0.01 \mathrm{DEF}_{\mathrm{APR}}-0.005 \mathrm{DEF}_{\mathrm{OCT}}+5.171$ & 0.029 & 3.74 & 0.70 & 2.44 & 0.71 \\
\hline \multicolumn{7}{|l|}{ June } \\
\hline BAU & $\mathrm{SS}=0.149 T_{\mathrm{JUN}}-0.002 P_{\mathrm{APR}}+1.112 \mathrm{RET}_{\mathrm{OCT}}-1.13$ & 0.013 & 1.38 & 0.92 & 1.16 & 0.78 \\
\hline BEB & $\mathrm{SS}=0.092 \mathrm{Tmax}_{\mathrm{AUG}}+0.001 \mathrm{EXC}_{\mathrm{FEB}}+0.006 \mathrm{STO}_{\mathrm{AUG}}-1.038$ & 0.014 & 1.34 & 0.84 & 4.59 & 0.71 \\
\hline LIM & $\mathrm{SS}=-0.017 \mathrm{Tmin}_{\mathrm{JUN}}+0.004 P_{\mathrm{MAY}}+0.003 P_{\mathrm{SEP}}+2.007$ & 0.025 & 2.06 & 0.72 & 0.85 & 0.98 \\
\hline MAT & $\mathrm{SS}=0.045 \mathrm{Tmin}_{\mathrm{MAY}}-0.05 \operatorname{Tmax}_{\mathrm{OCT}}+0.008 \mathrm{DEF}_{\mathrm{APR}}+3.623$ & 0.041 & 3.18 & 0.65 & 2.81 & 0.75 \\
\hline \multicolumn{7}{|l|}{ July } \\
\hline BAU & $\mathrm{SS}=0.085 T_{\mathrm{MAY}}-0.069 \operatorname{Tmax}_{\mathrm{FEB}}+0.171 \operatorname{Tmax}_{\mathrm{AUG}}-2.233$ & 0.009 & 1.15 & 0.94 & 0.59 & 0.71 \\
\hline BEB & $\mathrm{SS}=0.209 \mathrm{Tmax}_{\mathrm{MAY}}+0.003 \mathrm{EXC}_{\mathrm{DEC}}+0.006 \mathrm{STO}_{\mathrm{MAY}}-4.424$ & 0.007 & 1.03 & 0.90 & 3.08 & 0.94 \\
\hline LIM & $\mathrm{SS}=-0.075 \operatorname{Tmax}_{\mathrm{SEP}}-0.001 \mathrm{EXC}_{\mathrm{FEB}}+0.004 \mathrm{STO}_{\mathrm{SEP}}+5.003$ & 0.001 & 0.91 & 0.95 & 1.10 & 0.99 \\
\hline MAT & $\mathrm{SS}=0.062 T_{\mathrm{SEP}}+0.036 T \mathrm{~min}_{\mathrm{MAY}}-0.099 T \mathrm{max}_{\mathrm{DEC}}+4.163$ & 0.047 & 2.01 & 0.63 & 3.11 & 0.78 \\
\hline \multicolumn{7}{|l|}{ August } \\
\hline BAU & $\mathrm{SS}=0.145 \operatorname{Tmax}_{\mathrm{AUG}}+0.001 P_{\mathrm{JUL}}+0.002 P_{\mathrm{OCT}}-2.332$ & 0.016 & 1.24 & 0.91 & 1.10 & 0.89 \\
\hline BEB & $\mathrm{SS}=-0.093 T \mathrm{~min}_{\mathrm{APR}}-0.085 T \mathrm{max}_{\mathrm{JUL}}-0.005 P_{\mathrm{APR}}+7.203$ & 0.002 & 0.80 & 0.94 & 5.73 & 0.68 \\
\hline LIM & $\mathrm{SS}=0.003 P_{\mathrm{MAY}}+0.005 P_{\mathrm{SEP}}-0.238 \mathrm{RET}_{\mathrm{AUG}}+2.468$ & 0.003 & 1.32 & 0.88 & 0.50 & 0.99 \\
\hline MAT & $\mathrm{SS}=0.291 \mathrm{Tmax}_{\mathrm{MAY}}-0.005 \mathrm{DEF}_{\mathrm{OCT}}+0.001 \mathrm{EXC}_{\mathrm{FEB}}-6.034$ & 0.008 & 1.51 & 0.83 & 1.67 & 0.87 \\
\hline \multicolumn{7}{|c|}{ September } \\
\hline BAU & $\mathrm{SS}=-0.129 T \max _{\mathrm{APR}}-0.067 T \max _{\mathrm{DEC}}+0.008 \mathrm{DEF}_{\mathrm{JUL}}+9.095$ & 0.008 & 1.14 & 0.94 & 1.83 & 0.76 \\
\hline BEB & $\mathrm{SS}=0.115 T_{\mathrm{MAY}}-0.08 T \mathrm{~min}_{\mathrm{MAR}}-0.158 T \max _{\mathrm{DEC}}+7.40$ & 0.032 & 1.59 & 0.77 & 3.71 & 0.78 \\
\hline LIM & $\mathrm{SS}=-0.087 T \mathrm{~min}_{\mathrm{FEB}}-0.04 T \mathrm{~min}_{\mathrm{OCT}}+0.003 P_{\mathrm{SEP}}+4.479$ & 0.007 & 1.61 & 0.83 & 2.38 & 0.98 \\
\hline MAT & $\mathrm{SS}=-0.192 T \max _{\mathrm{JUL}}+0.072 T \max _{\mathrm{AUG}}-0.006 P_{\mathrm{APR}}+6.851$ & 0.046 & 3.24 & 0.64 & 2.40 & 0.81 \\
\hline \multicolumn{7}{|l|}{ October } \\
\hline BAU & $\mathrm{SS}=0.063 T_{\mathrm{OCT}}-0.058 T \min _{\mathrm{AUG}}-0.143 T \max _{\mathrm{APR}}+6.253$ & 0.001 & 0.24 & 0.99 & 3.20 & 0.91 \\
\hline $\mathrm{BEB}$ & $\mathrm{SS}=-0.109 \mathrm{Tmin}_{\mathrm{AUG}}-0.004 \mathrm{EXC}_{\mathrm{MAR}}-0.011 \mathrm{STO}_{\mathrm{JUN}}+4.755$ & 0.010 & 1.74 & 0.87 & 4.22 & 0.87 \\
\hline LIM & $\mathrm{SS}=-0.122 T_{\mathrm{FEB}}-0.002 P_{\mathrm{OCT}}+0.002 \mathrm{EXC}_{\mathrm{DEC}}+5.873$ & 0.004 & 1.31 & 0.87 & 3.10 & 0.95 \\
\hline MAT & $\mathrm{SS}=0.483 T_{\mathrm{APR}}-0.215 T_{\mathrm{OCT}}+0.134 T \max _{\mathrm{AUG}}-7.685$ & 0.010 & 3.06 & 0.81 & 3.03 & 0.91 \\
\hline \multicolumn{7}{|c|}{ November } \\
\hline BAU & $\mathrm{SS}=0.002 P_{\mathrm{DEC}}-0.011 \mathrm{STO}_{\mathrm{SEP}}+0.938 \mathrm{RET}_{\mathrm{OCT}}+1.828$ & 0.036 & 1.88 & 0.84 & 2.25 & 0.87 \\
\hline BEB & $\mathrm{SS}=0.069 \mathrm{Tmin}_{\mathrm{NOV}}+0.119 T \max _{\mathrm{JAN}}-0.007 \mathrm{DEF}_{\mathrm{MAY}}-2.004$ & 0.004 & 0.94 & 0.92 & 12.96 & 0.76 \\
\hline LIM & $\mathrm{SS}=0.105 T_{\mathrm{DEC}}+0.004 \mathrm{EXC}_{\mathrm{DEC}}+0.006 \mathrm{STO}_{\mathrm{MAY}}-0.347$ & 0.007 & 1.76 & 0.83 & 3.58 & 0.91 \\
\hline MAT & $\mathrm{SS}=-0.237 T \min _{\mathrm{AUG}}+0.016 P_{\mathrm{MAY}}+0.041 \mathrm{DEF}_{\mathrm{JUN}}+3.358$ & 0.007 & 3.09 & 0.83 & 7.18 & 0.70 \\
\hline \multicolumn{7}{|c|}{ December } \\
\hline BAU & $\mathrm{SS}=0.136 \mathrm{Tmin}_{\mathrm{MAR}}+0.122 \operatorname{Tmax}_{\mathrm{MAY}}-0.008 \mathrm{EXC}_{\mathrm{MAR}}-2.806$ & 0.001 & 0.41 & 0.99 & 5.20 & 0.85 \\
\hline $\mathrm{BEB}$ & $\mathrm{SS}=-0.331 T_{\mathrm{FEB}}-0.267 \operatorname{Tmax}_{\mathrm{DEC}}+0.003 P_{\mathrm{JAN}}+19.449$ & 0.029 & 2.32 & 0.78 & 11.36 & 0.78 \\
\hline LIM & $\mathrm{SS}=-0.10 T_{\mathrm{MAR}}+0.003 \mathrm{EXC}_{\mathrm{DEC}}+0.01 \mathrm{STO}_{\mathrm{AUG}}+4.575$ & 0.004 & 1.96 & 0.87 & 1.73 & 0.99 \\
\hline MAT & $\mathrm{SS}=-0.239 T_{\mathrm{NOV}}+0.096 \mathrm{Tmax}_{\mathrm{MAR}}-0.009 P_{\mathrm{JUN}}+5.512$ & 0.035 & 3.46 & 0.68 & 12.54 & 0.75 \\
\hline
\end{tabular}

The dependent variable is for the production year (year 2). Calibration and testing used monthly data from 2001 to 2009 and 2010-2013, respectively The independent variables are Tmin, $T$, and Tmax minimum, mean, and maximum air temperature $\left({ }^{\circ} \mathrm{C}\right) ; E X C$ and $D E F$ hydric excess and deficit; $S T O$ soil-water storage; $P$ precipitation $(\mathrm{mm})$, and $R E T$ relative evapotranspiration for the developmental year (year 1)

$B A U$ Bauru, BEB Bebedouro. LIM Limeira, MAT Matão 
Table 5 Monthly agrometeorological models for forecasting citric acid percentage (ACIDITY) for the state of São Paulo

\begin{tabular}{|c|c|c|c|c|c|c|}
\hline \multicolumn{2}{|c|}{ Acidity $(A)$} & \multirow[t]{2}{*}{$P$ value } & \multicolumn{2}{|l|}{ Calibration } & \multicolumn{2}{|l|}{ Testing } \\
\hline & & & MAPE $(\%)$ & $R^{2}$ adj & MAPE $(\%)$ & $R^{2}$ adj \\
\hline \multicolumn{7}{|l|}{ April } \\
\hline BAU & $A=0.004 P_{\mathrm{APR}}+0.001 \mathrm{EXC}_{\mathrm{JAN}}-0.515 \mathrm{RET}_{\mathrm{JUN}}+2.436$ & 0.047 & 2.53 & 0.81 & 2.41 & 0.61 \\
\hline BEB & $A=0.238 \mathrm{Tmax}_{\mathrm{MAR}}+0.001 \mathrm{EXC}_{\mathrm{MAR}}-0.007 \mathrm{STO}_{\mathrm{OCT}}-5.594$ & 0.035 & 3.76 & 0.75 & 3.07 & 0.62 \\
\hline LIM & $A=-0.331 T_{\mathrm{JUL}}-0.038 \mathrm{Tmin}_{\mathrm{MAY}}-0.259 \mathrm{RET}_{\mathrm{JUL}}+8.946$ & 0.028 & 3.23 & 0.71 & 2.14 & 0.93 \\
\hline MAT & $A=0.373 T_{\mathrm{MAY}}-0.368 T_{\mathrm{NOV}}+0.181 \operatorname{Tmax}_{\mathrm{OCT}}-2.540$ & 0.040 & 8.49 & 0.66 & 10.35 & 0.92 \\
\hline \multicolumn{7}{|l|}{ May } \\
\hline BAU & $A=0.046 T \min _{\mathrm{NOV}}-0.003 P_{\mathrm{SEP}}+0.022 \mathrm{DEF}_{\mathrm{JUL}}+1.591$ & 0.009 & 1.71 & 0.94 & 4.52 & 0.95 \\
\hline BEB & $A=0.104 T_{\mathrm{APR}}-0.084 T \mathrm{~min}_{\mathrm{DEC}}+0.01 \mathrm{DEF}_{\mathrm{JUL}}+0.685$ & 0.038 & 2.68 & 0.74 & 5.11 & 0.94 \\
\hline LIM & $A=0.075 \mathrm{Tmin}_{\mathrm{JUN}}+0.117 \operatorname{Tmax}_{\mathrm{SEP}}+0.005 P_{\mathrm{AUG}}-2.447$ & 0.003 & 2.57 & 0.89 & 12.53 & 0.47 \\
\hline MAT & $A=0.263 T_{\mathrm{JUN}}+0.003 P_{\mathrm{FEB}}+0.005 \mathrm{STO}_{\mathrm{APR}}-3.775$ & 0.007 & 3.67 & 0.84 & 4.44 & 0.88 \\
\hline \multicolumn{7}{|l|}{ June } \\
\hline BAU & $A=-0.173 T_{\mathrm{SEP}}+0.003 \mathrm{DEF}_{\mathrm{OCT}}-0.002 \mathrm{EXC}_{\mathrm{DEC}}+5.511$ & 0.037 & 2.59 & 0.84 & 5.48 & 0.88 \\
\hline BEB & $A=0.073 \mathrm{Tmin}_{\mathrm{APR}}+0.034 \mathrm{Tmin}_{\mathrm{JUL}}-0.005 \mathrm{STO}_{\mathrm{JUL}}+0.573$ & 0.031 & 3.18 & 0.77 & 3.61 & 0.94 \\
\hline LIM & $A=-0.087 T_{\mathrm{FEB}}-0.122 T_{\mathrm{SEP}}+0.094 \operatorname{Tmax}_{\mathrm{DEC}}+3.316$ & 0.035 & 3.95 & 0.68 & 6.02 & 0.41 \\
\hline MAT & $A=0.006 \mathrm{STO}_{\mathrm{APR}}-0.007 \mathrm{STO}_{\mathrm{AUG}}-0.349 \mathrm{RET}_{\mathrm{OCT}}+1.973$ & 0.046 & 3.14 & 0.64 & 4.03 & 0.89 \\
\hline \multicolumn{7}{|l|}{ July } \\
\hline BAU & $A=-0.150 T \max _{\mathrm{MAR}}+0.045 \mathrm{Tmax}_{\mathrm{JUN}}-0.004 \mathrm{STO}_{\mathrm{MAY}}+5.648$ & 0.009 & 1.92 & 0.94 & 4.13 & 0.89 \\
\hline BEB & $A=0.148 T_{\mathrm{AUG}}+0.045 T \mathrm{~min}_{\mathrm{JUL}}-0.06 T \mathrm{max}_{\mathrm{MAR}}-0.138$ & 0.020 & 2.35 & 0.82 & 5.47 & 0.88 \\
\hline LIM & $A=0.054 T_{\mathrm{JUN}}-0.098 T \max _{\mathrm{FEB}}+0.002 P_{\mathrm{APR}}+3.683$ & 0.027 & 3.01 & 0.71 & 6.08 & 0.70 \\
\hline MAT & $A=0.156 T \min _{\mathrm{APR}}-0.130 T \max _{\mathrm{FEB}}+0.164 T \max _{\mathrm{AUG}}-1.65$ & 0.025 & 4.52 & 0.72 & 7.43 & 0.87 \\
\hline \multicolumn{7}{|l|}{ August } \\
\hline BAU & $A=-0.052 T_{\mathrm{FEB}}-0.004 \mathrm{STO}_{\mathrm{JUL}}+0.491 \mathrm{RET}_{\mathrm{NOV}}+2.453$ & 0.003 & 0.82 & 0.97 & 2.77 & 0.77 \\
\hline $\mathrm{BEB}$ & $A=0.029 \operatorname{Tmin}_{\mathrm{JUL}}-0.078 \operatorname{Tmax}_{\mathrm{JUN}}+0.010 \mathrm{DEF}_{\mathrm{JUN}}+3.246$ & 0.026 & 2.80 & 0.79 & 5.66 & 0.87 \\
\hline LIM & $A=-0.097 T_{\mathrm{JUL}}-0.124 T \max _{\mathrm{FEB}}-0.001 . P_{\mathrm{JUL}}+7.361$ & 0.045 & 3.63 & 0.64 & 5.96 & 0.49 \\
\hline MAT & $A=0.096 T_{\mathrm{JUN}}+0.002 \mathrm{EXC}_{\mathrm{FEB}}+0.006 \mathrm{STO}_{\mathrm{APR}}-0.972$ & 0.025 & 4.72 & 0.72 & 9.90 & 0.79 \\
\hline \multicolumn{7}{|c|}{ September } \\
\hline BAU & $A=-0.029 T_{\mathrm{FEB}}-0.088 T_{\mathrm{SEP}}+0.004 \mathrm{DEF}_{\mathrm{APR}}+3.70$ & 0.003 & 1.01 & 0.97 & 2.52 & 0.89 \\
\hline BEB & $A=-0.062 \operatorname{Tmax}_{\mathrm{SEP}}-0.007 P_{\mathrm{JUL}}+0.006 \mathrm{DEF}_{\mathrm{SEP}}+3.27$ & 0.014 & 2.37 & 0.85 & 6.20 & 0.93 \\
\hline LIM & $A=-0.197 T_{\mathrm{FEB}}+0.031 T \min _{\mathrm{FEB}}+0.061 T \max _{\mathrm{OCT}}+3.343$ & 0.049 & 4.75 & 0.63 & 4.13 & 0.61 \\
\hline MAT & $A=-0.179 T_{\mathrm{FEB}}+0.078 T \min _{\mathrm{APR}}+0.089 \operatorname{Tmax}_{\mathrm{AUG}}+1.653$ & 0.004 & 2.89 & 0.87 & 10.66 & 0.92 \\
\hline \multicolumn{7}{|l|}{ October } \\
\hline BAU & $A=-0.089 T_{m_{M A R}}-1.112 \mathrm{RET}_{\mathrm{APR}}-0.525 \mathrm{RET}_{\mathrm{NOV}}+5.493$ & 0.006 & 1.76 & 0.96 & 2.52 & 0.77 \\
\hline BEB & $A=-0.058 T_{\mathrm{MAR}}-0.147 \operatorname{Tmax}_{\mathrm{MAY}}-0.006 \mathrm{STO}_{\mathrm{AUG}}+7.086$ & 0.046 & 4.94 & 0.72 & 12.87 & 0.78 \\
\hline LIM & $A=0.130 T_{\mathrm{MAY}}+0.034 T_{\mathrm{AUG}}-0.004 \mathrm{STO}_{\mathrm{SEP}}-1.968$ & 0.009 & 3.30 & 0.81 & 5.50 & 0.49 \\
\hline MAT & $A=-0.208 T_{\mathrm{JAN}}+0.255 T_{\mathrm{AUG}}+0.076 T \mathrm{max}_{\mathrm{AUG}}-1.935$ & 0.035 & 5.96 & 0.67 & 5.88 & 0.99 \\
\hline \multicolumn{7}{|c|}{ November } \\
\hline BAU & $A=0.103 T \max _{\mathrm{JUL}}-0.054 T \max _{\mathrm{DEC}}+0.001 P_{\mathrm{JUN}}-0.347$ & 0.011 & 2.14 & 0.93 & 4.68 & 0.92 \\
\hline BEB & $A=-0.053 T \min _{\mathrm{FEB}}-0.102 \operatorname{Tmax}_{\mathrm{MAY}}-0.005 \mathrm{STO}_{\mathrm{AUG}}+4.942$ & 0.046 & 3.92 & 0.72 & 17.79 & 0.46 \\
\hline LIM & $A=-0.077 T_{\mathrm{FEB}}+0.064 T_{\mathrm{DEC}}+0.022 T \mathrm{~min}_{\mathrm{JUN}}+1.066$ & 0.005 & 2.52 & 0.86 & 3.51 & 0.99 \\
\hline MAT & $A=0.050 T \min _{\mathrm{APR}}+0.074 T \max _{\mathrm{AUG}}-0.001 \mathrm{EXC}_{\mathrm{DEC}}-2.254$ & 0.019 & 4.46 & 0.75 & 12.66 & 0.72 \\
\hline \multicolumn{7}{|c|}{ December } \\
\hline BAU & $A=-0.071 T \min _{\mathrm{SEP}}+0.002 P_{\mathrm{JUL}}+0.005 \mathrm{DEF}_{\mathrm{NOV}}+1.178$ & 0.050 & 4.24 & 0.81 & 4.82 & 0.75 \\
\hline $\mathrm{BEB}$ & $A=-0.003 P_{\mathrm{SEP}}-0.001 \mathrm{EXC}_{\mathrm{JAN}}-0.002 \mathrm{EXC}_{\mathrm{MAR}}+0.968$ & 0.006 & 3.08 & 0.90 & 9.98 & 0.99 \\
\hline LIM & $A=-0.041 T_{\mathrm{FEB}}+0.027 T \mathrm{~min}_{\mathrm{JUN}}-0.001 P_{\mathrm{JUN}}+1.577$ & 0.019 & 4.91 & 0.75 & 6.00 & 0.59 \\
\hline MAT & $A=-0.095 \mathrm{Tmin}_{\mathrm{FEB}}+0.004 \mathrm{STO}_{\mathrm{APR}}-0.006 \mathrm{STO}_{\mathrm{AUG}}+2.198$ & 0.036 & 8.32 & 0.67 & 15.79 & 0.66 \\
\hline
\end{tabular}

The dependent variable is for the production year (year 2). Calibration and testing used monthly data from 2001 to 2009 and 2010-2013, respectively The independent variables are Tmin, $T$, and Tmax minimum, mean and maximum air temperature $\left({ }^{\circ} \mathrm{C}\right) ; E X C$ and $D E F$ hydric excess and deficit; $S T O$ soil-water storage; $P$ precipitation $(\mathrm{mm})$; and $R E T$ relative evapotranspiration for the developmental year (year 1).

$B A U$ Bauru, BEB Bebedouro, LIM Limeira, MAT Matão 
Table 6 Monthly agrometeorological models for forecasting sugar content (BRIX) for the state of São Paulo

\begin{tabular}{|c|c|c|c|c|c|c|}
\hline \multirow[t]{2}{*}{$\operatorname{BRIX}(B)$} & & \multirow[t]{2}{*}{$P$ value } & \multicolumn{2}{|l|}{ Calibration } & \multicolumn{2}{|l|}{ Testing } \\
\hline & & & MAPE $(\%)$ & $R^{2}$ adj & MAPE $(\%)$ & $R^{2}$ adj \\
\hline \multicolumn{7}{|l|}{ April } \\
\hline BAU & $B=0.091 T_{\mathrm{SEP}}-0.041 T \mathrm{~min}_{\mathrm{OCT}}-0.2 T \max _{\mathrm{MAR}}+13.649$ & 0.003 & 0.21 & 0.97 & 2.74 & 0.90 \\
\hline BEB & $B=0.33 . T_{\mathrm{JAN}}-0.378 T_{\mathrm{MAR}}+0.003_{\mathrm{FEB}}+9.367$ & 0.033 & 1.17 & 0.76 & 1.45 & 0.85 \\
\hline LIM & $B=-0.001 P_{\mathrm{JAN}}-0.005 \mathrm{STO}_{\mathrm{APR}}+9.189$ & 0.044 & 1.49 & 0.53 & 4.41 & 0.99 \\
\hline MAT & $B=-0.155 T_{\mathrm{JUL}}-0.008 \mathrm{STO}_{\mathrm{JUL}}+0.007 \mathrm{STO}_{\mathrm{NOV}}+12.078$ & 0.007 & 0.84 & 0.83 & 1.38 & 0.76 \\
\hline \multicolumn{7}{|l|}{ May } \\
\hline BAU & $B=0.027 T \mathrm{~min}_{\mathrm{JUN}}+0.002 P_{\mathrm{FEB}}-0.003 P_{\mathrm{JUL}}+8.716$ & 0.005 & 0.36 & 0.96 & 1.04 & 0.88 \\
\hline BEB & $B=0.335 T_{\mathrm{JAN}}-0.084 T \mathrm{~min}_{\mathrm{NOV}}+0.003 P_{\mathrm{DEC}}+1.699$ & 0.005 & 0.87 & 0.91 & 0.86 & 0.97 \\
\hline LIM & $B=0.005 P_{\mathrm{SEP}}+0.017 \mathrm{DEF}_{\mathrm{APR}}+0.011 \mathrm{STO}_{\mathrm{JUN}}+8.101$ & 0.006 & 0.92 & 0.84 & 1.59 & 0.82 \\
\hline MAT & $B=0.036 \mathrm{DEF}_{\mathrm{APR}}-0.021 \mathrm{DEF}_{\mathrm{OCT}}-0.014 \mathrm{STO}_{\mathrm{OCT}}+9.793$ & 0.001 & 0.71 & 0.94 & 2.62 & 0.77 \\
\hline \multicolumn{7}{|l|}{ June } \\
\hline BAU & $B=0.745 T_{\mathrm{JUN}}-0.584 \operatorname{Tmax}_{\mathrm{APR}}+0.01 \mathrm{EXC}_{\mathrm{MAR}}+15.111$ & 0.007 & 0.71 & 0.95 & 1.95 & 0.87 \\
\hline BEB & $B=0.182 T \max _{\mathrm{JAN}}+0.253 \operatorname{Tmax}_{\mathrm{MAY}}+0.003 P_{\mathrm{DEC}}-4.672$ & 0.007 & 0.82 & 0.90 & 1.02 & 0.98 \\
\hline LIM & $B=-0.005 P_{\mathrm{FEB}}+0.005 \mathrm{EXC}_{\mathrm{DEC}}+1.084 \mathrm{RET}_{\mathrm{AUG}}+9.595$ & 0.007 & 1.09 & 0.83 & 0.64 & 0.98 \\
\hline MAT & $B=-0.186 T_{\mathrm{OCT}}+0.237 \operatorname{Tmin}_{\mathrm{MAY}}+0.04 \mathrm{DEF}_{\mathrm{APR}}+12.304$ & 0.004 & 1.27 & 0.87 & 2.14 & 0.79 \\
\hline \multicolumn{7}{|l|}{ July } \\
\hline BAU & $B=-0.386 T_{\mathrm{FEB}}+0.471 T \max _{\mathrm{AUG}}-0.245 T \max _{\mathrm{SEP}}+13.139$ & 0.001 & 0.59 & 0.98 & 1.05 & 0.91 \\
\hline BEB & $B=0.132 T \mathrm{~min}_{\mathrm{SEP}}+0.007 P_{\mathrm{DEC}}-0.014 \mathrm{STO}_{\mathrm{JUN}}+8.523$ & 0.008 & 1.01 & 0.89 & 2.03 & 0.84 \\
\hline LIM & $B=-0.246 \operatorname{Tmax}_{\mathrm{SEP}}-0.004 \mathrm{EXC}_{\mathrm{FEB}}+0.012 \mathrm{STO}_{\mathrm{SEP}}+18.737$ & 0.001 & 0.98 & 0.93 & 1.32 & 0.99 \\
\hline MAT & $B=0.152 T \min _{\mathrm{MAY}}+0.191 T \max _{\mathrm{AUG}}-3.578 \mathrm{RET}_{\mathrm{APR}}+6.262$ & 0.009 & 1.60 & 0.81 & 2.82 & 0.94 \\
\hline \multicolumn{7}{|l|}{ August } \\
\hline BAU & $B=0.442 T \max _{\mathrm{AUG}}-0.003 P_{\mathrm{APR}}+0.004 P_{\mathrm{OCT}}-3.533$ & 0.040 & 1.51 & 0.83 & 0.99 & 0.81 \\
\hline $\mathrm{BEB}$ & $B=-0.872 T_{\mathrm{FEB}}-0.312 \operatorname{Tmin}_{\mathrm{AUG}}-0.028 P_{\mathrm{APR}}+38.829$ & 0.033 & 2.32 & 0.76 & 1.69 & 0.99 \\
\hline LIM & $B=-0.390 T_{\mathrm{FEB}}+0.011 P_{\mathrm{SEP}}+0.005 \mathrm{DEF}_{\mathrm{JUN}}+20.041$ & 0.003 & 1.03 & 0.89 & 1.07 & 0.93 \\
\hline MAT & $B=-0.307 \operatorname{Tmin}_{\mathrm{FEB}}+0.696 \operatorname{Tmax}_{\mathrm{MAY}}-0.016 \mathrm{STO}_{\mathrm{JUL}}-3.519$ & 0.004 & 1.51 & 0.86 & 3.83 & 0.97 \\
\hline \multicolumn{7}{|c|}{ September } \\
\hline BAU & $B=-0.294 T \max _{\mathrm{APR}}+0.248 T \max _{\mathrm{AUG}}-0.152 T \max _{\mathrm{DEC}}+17.800$ & 0.023 & 1.26 & 0.88 & 1.61 & 0.81 \\
\hline BEB & $B=-0.382 T \max _{\mathrm{JUN}}+0.482 \operatorname{Tmax}_{\mathrm{AUG}}-4.815 \mathrm{RET}_{\mathrm{APR}}+11.942$ & 0.002 & 0.82 & 0.94 & 2.49 & 0.91 \\
\hline LIM & $B=-0.342 T \min _{\mathrm{FEB}}+0.009 P_{\mathrm{SEP}}-0.004 P_{\mathrm{OCT}}+16.995$ & 0.003 & 1.49 & 0.89 & 1.46 & 0.92 \\
\hline MAT & $B=-0.75 T \max _{\mathrm{JUL}}+0.363 T \max _{\mathrm{AUG}}-0.027 P_{\mathrm{APR}}+25.165$ & 0.007 & 1.78 & 0.84 & 2.24 & 0.80 \\
\hline \multicolumn{7}{|l|}{ October } \\
\hline BAU & $B=-0.294 T \max _{\mathrm{APR}}+0.464 \operatorname{Tmax}_{\mathrm{AUG}}-0.009 \mathrm{STO}_{\mathrm{MAY}}+6.392$ & 0.011 & 1.42 & 0.93 & 2.14 & 0.82 \\
\hline BEB & $B=0.915 T \max _{\mathrm{JAN}}-0.014 P_{\mathrm{FEB}}-4.31 \mathrm{RET}_{\mathrm{APR}}-12.076$ & 0.014 & 1.92 & 0.85 & 2.34 & 0.95 \\
\hline LIM & $B=-0.516 T_{\mathrm{FEB}}+0.465 T_{\mathrm{MAY}}-0.194 T \min _{\mathrm{APR}}+17.813$ & 0.046 & 2.23 & 0.64 & 3.44 & 0.96 \\
\hline MAT & $B=-0.699 \mathrm{Tmin}_{\mathrm{AUG}}+0.054 P_{\mathrm{MAY}}+0.139 \mathrm{DEF}_{\mathrm{JUN}}+13.022$ & 0.031 & 3.40 & 0.69 & 3.33 & 0.95 \\
\hline \multicolumn{7}{|c|}{ November } \\
\hline BAU & $B=0.574 T_{\mathrm{JAN}}-0.58 T_{\mathrm{MAY}}-0.583 \operatorname{imax}_{\mathrm{DEC}}+27.47$ & 0.041 & 2.18 & 0.83 & 2.27 & 0.86 \\
\hline $\mathrm{BEB}$ & $B=-0.583 T_{\mathrm{MAY}}-0.402 \max _{\mathrm{SEP}}-0.016 P_{\mathrm{JUN}}+39.948$ & 0.037 & 1.37 & 0.75 & 12.10 & 0.61 \\
\hline LIM & $B=-0.198 T \min _{\mathrm{JAN}}+0.201 T \min _{\mathrm{MAY}}-0.229 T \max _{\mathrm{OCT}}+21.698$ & 0.009 & 1.55 & 0.82 & 2.44 & 0.93 \\
\hline MAT & $B=-0.775 \operatorname{Tmin}_{\mathrm{AUG}}+0.058 P_{\mathrm{MAY}}+0.15 \mathrm{DEF}_{\mathrm{JUN}}+13.39$ & 0.007 & 2.54 & 0.83 & 3.49 & 0.84 \\
\hline \multicolumn{7}{|c|}{ December } \\
\hline BAU & $B=-0.194 T \min _{\mathrm{NOV}}+0.386 T \min _{\mathrm{DEC}}-0.374 T \max _{\mathrm{DEC}}+19.995$ & 0.003 & 0.90 & 0.97 & 2.98 & 0.93 \\
\hline BEB & $B=-1.297 T_{\mathrm{FEB}}-1.11 \operatorname{Tmax}_{\mathrm{DEC}}+0.008 P_{\mathrm{JAN}}+80.413$ & 0.003 & 0.99 & 0.94 & 10.42 & 0.59 \\
\hline LIM & $B=0.231 \mathrm{Tmin}_{\mathrm{MAR}}-0.303 \mathrm{Tmax}_{\mathrm{OCT}}+0.03 \mathrm{STO}_{\mathrm{AUG}}+17.819$ & 0.007 & 1.64 & 0.83 & 2.81 & 0.99 \\
\hline MAT & $B=1.688 T \min _{\mathrm{APR}}-0.578 T \mathrm{~min}_{\mathrm{JUN}}+1.351 T \mathrm{max}_{\mathrm{AUG}}-52.002$ & 0.040 & 3.13 & 0.66 & 4.68 & 0.91 \\
\hline
\end{tabular}

The dependent variable is for the production year (year 2). Calibration and testing used monthly data from 2001-2009 and 2010-2013, respectively The independent variables are Tmin, $T$, and Tmax minimum, mean and maximum air temperature $\left({ }^{\circ} \mathrm{C}\right) ; E X C$ and $D E F$ hydric excess and deficit; $S T O$ soil-water storage; $P$ precipitation $(\mathrm{mm})$, and $R E T$ relative evapotranspiration for the developmental year (year 1)

$B A U$ Bauru, BEB Bebedouro, LIM Limeira, MAT Matão 
Table 7 Monthly agrometeorological models for forecasting juice percentage (\%JUICE) for the state of São Paulo

\begin{tabular}{|c|c|c|c|c|c|c|}
\hline \multicolumn{2}{|c|}{ \% JUICE $(J)$} & \multirow[t]{2}{*}{$P$ value } & \multicolumn{2}{|l|}{ Calibration } & \multicolumn{2}{|l|}{ Testing } \\
\hline & & & MAPE $(\%)$ & $R^{2}$ adj & MAPE $(\%)$ & $R^{2}$ adj \\
\hline \multicolumn{7}{|l|}{ April } \\
\hline BAU & $J=0.0005 P_{\mathrm{OCT}}-0.371 \mathrm{RET}_{\mathrm{APR}}-0.071 \mathrm{RET}_{\mathrm{JUL}}+0.832$ & 0.008 & 1.69 & 0.94 & 3.04 & 0.82 \\
\hline BEB & $J=0.010 T \min _{\mathrm{JUL}}-0.020 \operatorname{Tmax}_{\mathrm{FEB}}+0.001 \mathrm{EXC}_{\mathrm{DEC}}+1.065$ & 0.025 & 2.12 & 0.79 & 3.21 & 0.98 \\
\hline LIM & $J=0.012 T \min _{\mathrm{MAR}}+0.013 T \mathrm{~min}_{\mathrm{JUL}}+0.002 \mathrm{DEF}_{\mathrm{MAY}}+0.236$ & 0.006 & 2.52 & 0.85 & 1.60 & 0.91 \\
\hline MAT & $J=-0.031 T_{\mathrm{FEB}}-0.039 T_{\mathrm{JUN}}+0.001 \mathrm{DEF}_{\mathrm{APR}}+2.025$ & 0.018 & 3.01 & 0.75 & 2.57 & 0.98 \\
\hline \multicolumn{7}{|l|}{ May } \\
\hline BAU & $J=-0.005 \mathrm{Tmin}_{\mathrm{JUN}}+0.002 \mathrm{DEF}_{\mathrm{MAY}}+0.001 \mathrm{STO}_{\mathrm{OCT}}+0.530$ & 0.056 & 1.29 & 0.79 & 10.20 & 0.58 \\
\hline BEB & $J=0.008 T_{\mathrm{SEP}}+0.014 T \max _{\mathrm{FEB}}+0.0002 P_{\mathrm{JAN}}-0.180$ & 0.009 & 1.05 & 0.88 & 1.66 & 0.93 \\
\hline LIM & $J=-0.014 T \max _{\mathrm{JUN}}-0.007 \operatorname{Tmax}_{\mathrm{AUG}}+0.0002 P_{\mathrm{SEP}}+1.155$ & 0.039 & 1.29 & 0.66 & 1.89 & 0.89 \\
\hline MAT & $J=-0.008 T \min _{\mathrm{JUN}}+0.014 T \max _{\mathrm{FEB}}+0.001 P_{\mathrm{MAY}}+0.088$ & 0.004 & 1.45 & 0.87 & 2.58 & 0.98 \\
\hline \multicolumn{7}{|l|}{ June } \\
\hline BAU & $J=-0.019 T \max _{\mathrm{JAN}}-0.0003 P_{\mathrm{JUL}}+0.0001 P_{\mathrm{DEC}}+1.233$ & 0.041 & 0.92 & 0.83 & 0.54 & 0.96 \\
\hline BEB & $J=0.012 \operatorname{Tmax}_{\mathrm{AUG}}-0.001 \mathrm{DEF}_{\mathrm{AUG}}+0.001 \mathrm{STO}_{\mathrm{JUL}}+0.169$ & 0.046 & 1.51 & 0.72 & 1.18 & 0.89 \\
\hline LIM & $J=-0.004 \operatorname{Tmin}_{\mathrm{DEC}}+0.0004 P_{\mathrm{SEP}}+0.0002 \mathrm{STO}_{\mathrm{JUL}}+0.599$ & 0.036 & 1.13 & 0.67 & 0.59 & 0.88 \\
\hline MAT & $J=-0.010 T \max _{\mathrm{OCT}}+0.0003 P_{\mathrm{MAY}}+0.040 \mathrm{RET}_{\mathrm{SEP}}+0.881$ & 0.010 & 1.18 & 0.81 & 0.73 & 0.96 \\
\hline \multicolumn{7}{|l|}{ July } \\
\hline BAU & $J=0.005 T_{\mathrm{MAY}}-0.007 T \mathrm{~min}_{\mathrm{JAN}}-0.002 T \mathrm{~min}_{\mathrm{AUG}}+0.629$ & 0.006 & 0.21 & 0.95 & 0.82 & 0.95 \\
\hline $\mathrm{BEB}$ & $J=0.017 T_{\mathrm{JUN}}-0.001 \mathrm{DEF}_{\mathrm{OCT}}+0.001 \mathrm{STO}_{\mathrm{SEP}}+0.226$ & 0.049 & 1.40 & 0.71 & 1.44 & 0.84 \\
\hline LIM & $J=-0.006 T \min _{\mathrm{MAR}}-0.010 T \max _{\mathrm{DEC}}+0.0004 \mathrm{STO}_{\mathrm{SEP}}+0.997$ & 0.016 & 0.82 & 0.76 & 0.61 & 0.96 \\
\hline MAT & $J=-0.014 T_{\mathrm{JUN}}+0.0003 \mathrm{STO}_{\mathrm{JUN}}+0.0003 \mathrm{STO}_{\mathrm{NOV}}+0.819$ & 0.008 & 1.04 & 0.83 & 0.66 & 0.92 \\
\hline \multicolumn{7}{|l|}{ August } \\
\hline BAU & $J=0.004 \operatorname{Tmin}_{\mathrm{MAY}}-0.012 \mathrm{Tmin}_{\mathrm{JUL}}-0.0002 \mathrm{STO}_{\mathrm{NOV}}+0.649$ & 0.028 & 0.45 & 0.87 & 0.78 & 0.81 \\
\hline BEB & $J=0.012 \operatorname{Tmax}_{\mathrm{JUN}}+0.0002 \mathrm{EXC}_{\mathrm{DEC}}+0.001 \mathrm{STO}_{\mathrm{MAY}}+0.154$ & 0.026 & 1.23 & 0.79 & 1.39 & 0.86 \\
\hline LIM & $J=0.011 T \max _{\mathrm{FEB}}-0.0001 P_{\mathrm{MAR}}+0.0003 \mathrm{EXC}_{\mathrm{DEC}}+0.242$ & 0.004 & 0.59 & 0.87 & 0.79 & 0.86 \\
\hline MAT & $J=0.018 T_{\mathrm{SEP}}-0.0001 P_{\mathrm{FEB}}+0.0005 \mathrm{STO}_{\mathrm{OCT}}+0.189$ & 0.039 & 2.09 & 0.66 & 0.92 & 0.81 \\
\hline \multicolumn{7}{|c|}{ September } \\
\hline BAU & $J=-0.008 T_{\mathrm{OCT}}-0.005 T \min _{\mathrm{SEP}}+0.006 T \mathrm{~min}_{\mathrm{DEC}}+0.723$ & 0.027 & 0.56 & 0.87 & 0.95 & 0.83 \\
\hline BEB & $J=0.0001 \mathrm{EXC}_{\mathrm{JAN}}-0.0003 \mathrm{EXC}_{\mathrm{DEC}}+0.0009 \mathrm{STO}_{\mathrm{OCT}}+0.575$ & 0.002 & 0.44 & 0.95 & 0.72 & 0.99 \\
\hline LIM & $J=-0.022 T_{\mathrm{APR}}+0.003 T \mathrm{~min}_{\mathrm{MAY}}+0.0001 \mathrm{EXC}_{\mathrm{FEB}}+1.058$ & 0.010 & 0.68 & 0.81 & 0.81 & 0.90 \\
\hline MAT & $J=0.006 T \max _{\mathrm{SEP}}-0.010 T \max _{\mathrm{OCT}}+0.0002 \mathrm{STO}_{\mathrm{JUN}}+0.719$ & 0.006 & 0.89 & 0.84 & 0.51 & 0.83 \\
\hline \multicolumn{7}{|l|}{ October } \\
\hline BAU & $J=-0.012 T_{\mathrm{APR}}-0.014 T \mathrm{~min}_{\mathrm{JUL}}-0.073 \mathrm{RET}_{\mathrm{APR}}+1.010$ & 0.017 & 0.38 & 0.91 & 0.67 & 0.95 \\
\hline $\mathrm{BEB}$ & $J=0.003 \mathrm{Tmin}_{\mathrm{JUN}}+0.001 \mathrm{STO}_{\mathrm{OCT}}-0.0005 \mathrm{STO}_{\mathrm{NOV}}+0.561$ & 0.012 & 0.77 & 0.86 & 1.04 & 0.96 \\
\hline LIM & $J=0.004 T \mathrm{~min}_{\mathrm{JUL}}+0.015 T \mathrm{max}_{\mathrm{JAN}}-0.0003 P_{\mathrm{MAR}}+0.133$ & 0.009 & 0.94 & 0.82 & 2.29 & 0.98 \\
\hline MAT & $J=0.003 T \min _{\mathrm{SEP}}-0.007 T \mathrm{~min}_{\mathrm{NOV}}+0.0004 \mathrm{STO}_{\mathrm{OCT}}+0.627$ & 0.005 & 1.28 & 0.86 & 0.41 & 0.95 \\
\hline \multicolumn{7}{|c|}{ November } \\
\hline BAU & $J=0.005 T_{\mathrm{AUG}}-0.018 T \max _{\mathrm{MAR}}-0.009 T \max _{\mathrm{DEC}}+1.417$ & 0.041 & 0.94 & 0.83 & 0.84 & 0.89 \\
\hline BEB & $J=0.005 T \max _{\mathrm{SEP}}+0.006 T \max _{\mathrm{OCT}}+0.001 \mathrm{STO}_{\mathrm{AUG}}+0.166$ & 0.004 & 0.48 & 0.92 & 2.13 & 0.89 \\
\hline LIM & $J=-0.004 \mathrm{Tmin}_{\mathrm{JAN}}-0.0002 \mathrm{EXC}_{\mathrm{FEB}}+0.093 \mathrm{RET}_{\mathrm{OCT}}+0.585$ & 0.021 & 1.33 & 0.74 & 0.77 & 0.99 \\
\hline MAT & $J=0.010 T_{\mathrm{SEP}}+0.005 \operatorname{Tmax}_{\mathrm{JAN}}+0.0003 \mathrm{EXC}_{\mathrm{MAR}}+0.147$ & 0.041 & 1.27 & 0.65 & 2.15 & 0.76 \\
\hline \multicolumn{7}{|c|}{ December } \\
\hline BAU & $J=0.0003 \mathrm{DEF}_{\mathrm{JUN}}-0.0004 \mathrm{STO}_{\mathrm{JUL}}+0.116 \mathrm{RET}_{\mathrm{APR}}+0.507$ & 0.046 & 0.57 & 0.82 & 0.51 & 0.98 \\
\hline BEB & $J=-0.012 T_{\mathrm{JUL}}+0.0003 P_{\mathrm{JAN}}+0.0001 P_{\mathrm{DEC}}+0.714$ & 0.025 & 0.73 & 0.79 & 2.22 & 0.92 \\
\hline LIM & $J=0.001 \mathrm{STO}_{\mathrm{JUN}}-0.151 \mathrm{RET}_{\mathrm{MAY}}+0.658$ & 0.008 & 1.80 & 0.73 & 4.19 & 0.88 \\
\hline MAT & $J=0.016 T \max _{\mathrm{AUG}}+0.001 P_{\mathrm{MAY}}-0.0005 P_{\mathrm{JUN}}-0.023$ & 0.003 & 1.05 & 0.88 & 9.91 & 0.72 \\
\hline
\end{tabular}

The dependent variable is for the production year (year 2). Calibration and testing used monthly data from 2001-2009 and 2010-2013, respectively The independent variables are $T \mathrm{~min}, T$, and $T$ max minimum, mean and maximum air temperature $\left({ }^{\circ} \mathrm{C}\right) ; E X C$ and $D E F$ hydric excess and deficit; $S T O$ soil-water storage; $P$ precipitation $(\mathrm{mm})$; and $R E T$ relative evapotranspiration for the developmental year (year 1)

$B A U$ Bauru, BEB Bebedouro, LIM Limeira, MAT Matão 
Table 8 Monthly forecast agrometeorological models of fruits per box (FRBOX) for the State of São Paulo

\begin{tabular}{|c|c|c|c|c|c|c|}
\hline \multicolumn{2}{|c|}{$\operatorname{FRBOX}(F)$} & \multirow[t]{2}{*}{$P$ value } & \multicolumn{2}{|l|}{ Calibration } & \multicolumn{2}{|l|}{ Testing } \\
\hline & & & MAPE (\%) & $R^{2}$ adj & MAPE (\%) & $R^{2}$ adj \\
\hline \multicolumn{7}{|l|}{ April } \\
\hline BAU & $F=4.97 \mathrm{Tmin}_{\mathrm{SEP}}+4.119 \mathrm{Tmax}_{\mathrm{JUN}}+2.166 \mathrm{DEF}_{\mathrm{JUL}}+186.485$ & 0.005 & 0.70 & 0.96 & 2.38 & 0.90 \\
\hline BEB & $F=5.483 \mathrm{Tmin}_{\mathrm{SEP}}+2.146 \mathrm{DEF}_{\mathrm{MAY}}+94.26 \mathrm{RET}_{\mathrm{OCT}}+203.71$ & 0.033 & 2.64 & 0.76 & 5.18 & 0.89 \\
\hline LIM & $F=-30.219 T_{\mathrm{JUL}}-11.67 \mathrm{Tmax}_{\mathrm{NOV}}-0.942 \mathrm{STO}_{\mathrm{APR}}+1375.923$ & 0.023 & 2.00 & 0.73 & 1.29 & 0.97 \\
\hline MAT & $F=61.826 T_{\mathrm{JAN}}-19.694 T \mathrm{~min}_{\mathrm{MAR}}-14.624 T \mathrm{max}_{\mathrm{JAN}}-347.925$ & 0.006 & 2.33 & 0.85 & 4.06 & 0.97 \\
\hline \multicolumn{7}{|l|}{ May } \\
\hline BAU & $F=-0.204 P_{\mathrm{JUN}}+4.157 \mathrm{DEF}_{\mathrm{JUL}}+0.60 \mathrm{DEF}_{\mathrm{NOV}}+271.378$ & 0.015 & 2.74 & 0.91 & 2.94 & 0.87 \\
\hline BEB & $F=-7.512 T \min _{\mathrm{DEC}}+12.541 \mathrm{Tmax}_{\mathrm{AUG}}+0.387 \mathrm{EXC}_{\mathrm{FEB}}-14.254$ & 0.025 & 2.17 & 0.80 & 8.52 & 0.50 \\
\hline LIM & $F=-21.293 T_{\mathrm{MAR}}-22.269 T_{\mathrm{APR}}+32.592 T_{\mathrm{JUN}}+729.577$ & 0.001 & 0.99 & 0.95 & 8.90 & 0.48 \\
\hline MAT & $F=32.726 T_{\mathrm{APR}}-15.739 T \max _{\mathrm{FEB}}+14.929 T \max _{\mathrm{AUG}}-412.735$ & 0.027 & 3.05 & 0.71 & 1.68 & 0.97 \\
\hline \multicolumn{7}{|l|}{ June } \\
\hline BAU & $F=-33.826 T_{\mathrm{SEP}}+6.289 \operatorname{Tmax}_{\mathrm{AUG}}+1.125 \mathrm{DEF}_{\mathrm{JUN}}+789.071$ & 0.033 & 3.46 & 0.86 & 1.96 & 0.91 \\
\hline BEB & $F=-21.703 T \min _{\mathrm{FEB}}-15.161 \operatorname{Tmax}_{\mathrm{APR}}-1.507 \mathrm{STO}_{\mathrm{JUL}}+1201.989$ & 0.027 & 1.55 & 0.78 & 3.33 & 0.75 \\
\hline LIM & $F=0.873 \mathrm{DEF}_{\mathrm{JUL}}+0.140 \mathrm{EXC}_{\mathrm{JAN}}+28.71 \mathrm{RET}_{\mathrm{OCT}}+224.261$ & 0.049 & 2.42 & 0.63 & 6.35 & 0.80 \\
\hline MAT & $F=18.157 T_{\mathrm{APR}}-21.632 T_{\mathrm{DEC}}+1.032 \mathrm{DEF}_{\mathrm{JUL}}+377.587$ & 0.020 & 2.68 & 0.74 & 6.08 & 0.70 \\
\hline \multicolumn{7}{|l|}{ July } \\
\hline BAU & $F=-36.681 \operatorname{Tmax}_{\mathrm{MAR}}-405.983 \mathrm{RET}_{\mathrm{APR}}-258.039 . \mathrm{RET}_{\mathrm{NOV}}+2117.624$ & 0.006 & 2.18 & 0.96 & 4.44 & 0.87 \\
\hline $\mathrm{BEB}$ & $F=4.160 T \min _{\mathrm{JUN}}-8.709 \operatorname{Tmax}_{\mathrm{MAR}}-23.884 T \mathrm{max}_{\mathrm{DEC}}+1343.182$ & 0.013 & 2.04 & 0.85 & 3.22 & 0.84 \\
\hline LIM & $F=12.152 T \max _{\mathrm{JAN}}-14.744 T \max _{\mathrm{FEB}}-20.168 T \max _{\mathrm{JUL}}+968.44$ & 0.046 & 1.85 & 0.64 & 2.78 & 0.75 \\
\hline MAT & $F=-34.704 T \max _{\mathrm{JUL}}-0.973 P_{\mathrm{JUL}}-1.587 \mathrm{STO}_{\mathrm{JUN}}+1443.003$ & 0.045 & 4.62 & 0.64 & 7.66 & 0.89 \\
\hline \multicolumn{7}{|l|}{ August } \\
\hline BAU & $F=1.847 \mathrm{DEF}_{\mathrm{APR}}+2.084 \mathrm{DEF}_{\mathrm{JUL}}+232.573$ & 0.041 & 5.30 & 0.70 & 2.40 & 0.88 \\
\hline BEB & $F=-8.856 T \min _{\mathrm{FEB}}-0.817 P_{\mathrm{JUN}}+0.366 \mathrm{EXC}_{\mathrm{DEC}}+422.314$ & 0.033 & 2.84 & 0.76 & 3.76 & 0.83 \\
\hline LIM & $F=18.795 T_{\mathrm{JUN}}+21.193 T_{\mathrm{JUL}}+0.509 \mathrm{STO}_{\mathrm{MAY}}-494.225$ & 0.048 & 2.42 & 0.63 & 6.73 & 0.46 \\
\hline MAT & $F=12.964 T_{m^{2}}{ }_{\mathrm{MAY}}-0.720 P_{\mathrm{JUN}}-0.284 P_{\mathrm{JUL}}+185.629$ & 0.010 & 2.88 & 0.81 & 7.78 & 0.69 \\
\hline \multicolumn{7}{|c|}{ September } \\
\hline BAU & $F=-17.937 T_{\mathrm{APR}}-14.087 T_{\mathrm{SEP}}+0.898 \mathrm{DEF}_{\mathrm{APR}}+947.348$ & 0.003 & 1.18 & 0.97 & 0.84 & 0.97 \\
\hline BEB & $F=3.389 T_{m_{a x}}{ }_{\mathrm{AUG}}-0.561 P_{\mathrm{JUN}}+0.428 \mathrm{STO}_{\mathrm{OCT}}+163.844$ & 0.026 & 1.13 & 0.79 & 8.68 & 0.92 \\
\hline LIM & $F=54.117 T_{\mathrm{APR}}-19.010 T \min _{\mathrm{OCT}}+18.637 T \mathrm{max}_{\mathrm{JAN}}-1348.077$ & 0.014 & 2.41 & 0.78 & 3.88 & 0.97 \\
\hline MAT & $F=-14.345 \mathrm{Tmin}_{\mathrm{FEB}}+2.760 \mathrm{Tmin}_{\mathrm{JUL}}+494.262$ & 0.042 & 3.99 & 0.54 & 19.52 & 0.54 \\
\hline \multicolumn{7}{|l|}{ October } \\
\hline BAU & $F=-10.745 T_{\mathrm{MAY}}+1.402 \mathrm{DEF}_{\mathrm{JUL}}-215.866 \mathrm{RET}_{\mathrm{APR}}+612.989$ & 0.005 & 1.88 & 0.96 & 1.97 & 0.98 \\
\hline $\mathrm{BEB}$ & $F=-48.124 \operatorname{Tmax}_{\mathrm{MAY}}+14.471 T \max _{\mathrm{AUG}}-0.966 \mathrm{STO}_{\mathrm{JUN}}+1284.979$ & 0.019 & 3.70 & 0.82 & 6.24 & 0.70 \\
\hline LIM & $F=10.264 T \min _{\mathrm{MAY}}-10.343 T \min _{\mathrm{OCT}}+10.322 \operatorname{Tmax}_{\mathrm{MAY}}-3.819$ & 0.009 & 2.34 & 0.82 & 6.58 & 0.99 \\
\hline MAT & $F=56.203 T_{\mathrm{APR}}+0.392 P_{\mathrm{FEB}}+1.013 \mathrm{STO}_{\mathrm{APR}}-1212.05$ & 0.025 & 7.48 & 0.72 & 10.59 & 0.65 \\
\hline \multicolumn{7}{|c|}{ November } \\
\hline BAU & $F=-22.52 T_{\mathrm{SEP}}-6.972 T \min _{\mathrm{APR}}+2.731 \mathrm{DEF}_{\mathrm{APR}}+769.865$ & 0.012 & 2.83 & 0.93 & 3.13 & 0.88 \\
\hline BEB & $F=-12.683 T \min _{\mathrm{FEB}}+5.513 T \mathrm{~min}_{\mathrm{JUL}}-1.17 \mathrm{STO}_{\mathrm{JUN}}+482.179$ & 0.046 & 2.95 & 0.72 & 8.67 & 0.51 \\
\hline LIM & $F=6.388 T \min _{\mathrm{JUN}}+9.775 \operatorname{Tmax}_{\mathrm{JAN}}-12.213 \operatorname{Tmax}_{\mathrm{AUG}}+273.692$ & 0.027 & 3.28 & 0.71 & 4.51 & 0.81 \\
\hline MAT & $F=43.551 T_{\mathrm{MAY}}-16.646 T \min _{\mathrm{NOV}}+15.694 T \max _{\mathrm{AUG}}-949.132$ & 0.024 & 6.46 & 0.72 & 6.37 & 0.85 \\
\hline \multicolumn{7}{|c|}{ December } \\
\hline BAU & $F=-31.676 T_{\mathrm{SEP}}-0.744 P_{\mathrm{MAR}}+0.275 \mathrm{EXC}_{\mathrm{DEC}}+985.551$ & 0.004 & 2.00 & 0.96 & 5.88 & 0.71 \\
\hline BEB & $F=-14.757 \mathrm{Tmax}_{\mathrm{JUL}}+0.442 P_{\mathrm{OCT}}-151.708 \mathrm{RET}_{\mathrm{JUN}}+748.429$ & 0.046 & 2.94 & 0.72 & 8.96 & 0.69 \\
\hline LIM & $F=0.96 P_{\mathrm{JUN}}+0.765 P_{\mathrm{AUG}}-0.841 \mathrm{STO}_{\mathrm{OCT}}+216.073$ & 0.047 & 4.85 & 0.63 & 6.73 & 0.85 \\
\hline MAT & $F=26.724 T_{\mathrm{JUN}}+62.866 T_{\mathrm{JUL}}-25.581 \mathrm{Tmax}_{\mathrm{JUL}}-759.015$ & 0.037 & 10.46 & 0.67 & 12.14 & 0.78 \\
\hline
\end{tabular}

The independent variables are Tmin, $T$, Tmax minimum, mean, and maximum air temperature $\left({ }^{\circ} \mathrm{C}\right) ; E X C$ and $D E F$ hydric excess and deficit; $S T O$ soilwater storage; $P$ precipitation $(\mathrm{mm}$ ); and $R E T$ relative evapotranspiration, referents to the developmental year (year 1 ) and the dependent variable is referent to the production year (year 2). Calibration and testing used monthly data from 2001 to 2009 and 2010-2013, respectively

$B A U$ Bauru, BEB Bebedouro, LIM Limeira, MAT Matão 
Table 9 Monthly agrometeorological models for forecasting fruit weight (WFRUIT) for the state of São Paulo

\begin{tabular}{|c|c|c|c|c|c|c|}
\hline \multicolumn{2}{|c|}{ WFRUIT $(W)$} & \multirow[t]{2}{*}{$P$ value } & \multicolumn{2}{|l|}{ Calibration } & \multicolumn{2}{|l|}{ Testing } \\
\hline & & & MAPE $(\%)$ & $R^{2}$ adj & MAPE $(\%)$ & $R^{2}$ adj \\
\hline \multicolumn{7}{|l|}{ April } \\
\hline BAU & $W=-0.002 T_{m_{\text {min }}}$ SEP $-0.001 \max _{\mathrm{JUN}}+0.035 \mathrm{RET}_{\mathrm{JUL}}+0.132$ & 0.002 & 0.46 & 0.98 & 2.52 & 0.95 \\
\hline BEB & $W=-0.007 \operatorname{Tmax}_{\mathrm{AUG}}+0.0001 \mathrm{DEF}_{\mathrm{SEP}}+0.0001 \mathrm{EXC}_{\mathrm{MAR}}+0.338$ & 0.044 & 2.79 & 0.72 & 5.53 & 0.50 \\
\hline LIM & $W=0.008 T_{\mathrm{JUL}}+0.004 \mathrm{Tmax}_{\mathrm{NOV}}+0.0003 \mathrm{STO}_{\mathrm{APR}}-0.186$ & 0.031 & 1.68 & 0.69 & 2.76 & 0.81 \\
\hline MAT & $W=-0.004 T_{\mathrm{JUN}}-0.005 T \min _{\mathrm{JAN}}+0.0001 P_{\mathrm{APR}}+0.283$ & 0.023 & 2.86 & 0.73 & 2.82 & 0.93 \\
\hline \multicolumn{7}{|l|}{ May } \\
\hline BAU & $W=0.004 T \min _{\mathrm{AUG}}+0.005 T \max _{\mathrm{FEB}}+0.0003 \mathrm{STO}_{\mathrm{JUL}}-0.082$ & 0.035 & 3.21 & 0.85 & 1.92 & 0.96 \\
\hline BEB & $W=0.011 T_{\mathrm{JAN}}-0.010 \operatorname{Tmax}_{\mathrm{AUG}}-0.0002 \mathrm{EXC}_{\mathrm{FEB}}+0.212$ & 0.024 & 2.58 & 0.80 & 7.17 & 0.49 \\
\hline LIM & $W=0.011 T_{\mathrm{MAR}}-0.009 T_{\mathrm{JUN}}-0.00004 P_{\mathrm{NOV}}+0.036$ & 0.014 & 2.49 & 0.78 & 3.00 & 0.49 \\
\hline MAT & $W=0.011 T_{\mathrm{NOV}}+0.010 T \min _{\mathrm{FEB}}-0.001 \mathrm{DEF}_{\mathrm{JUL}}-0.274$ & 0.023 & 3.36 & 0.73 & 3.93 & 0.84 \\
\hline \multicolumn{7}{|l|}{ June } \\
\hline BAU & $W=0.020 T_{\mathrm{SEP}}-0.001 \mathrm{Tmin}_{\mathrm{JUN}}+0.027 \mathrm{RET}_{\mathrm{JUN}}-0.288$ & 0.005 & 1.82 & 0.96 & 1.48 & 0.97 \\
\hline BEB & $W=0.008 \operatorname{Tmin}_{\mathrm{FEB}}-0.0001 P_{\mathrm{JAN}}+0.001 \mathrm{STO}_{\mathrm{JUL}}+0.022$ & 0.018 & 1.41 & 0.83 & 3.13 & 0.83 \\
\hline LIM & $W=-0.008 T_{\mathrm{JUN}}+0.006 T_{\mathrm{OCT}}-0.0001 P_{\mathrm{MAR}}+0.175$ & 0.049 & 2.85 & 0.63 & 3.61 & 0.87 \\
\hline MAT & $W=0.012 T \max _{\mathrm{JUL}}+0.0004 P_{\mathrm{JUL}}+0.001 \mathrm{STO}_{\mathrm{JUN}}-0.254$ & 0.039 & 3.50 & 0.66 & 6.08 & 0.62 \\
\hline \multicolumn{7}{|l|}{ July } \\
\hline BAU & $W=0.020 \mathrm{Tmax}_{\mathrm{MAR}}+0.194 \mathrm{RET}_{\mathrm{APR}}+0.151 \mathrm{RET}_{\mathrm{NOV}}-0.838$ & 0.007 & 2.46 & 0.95 & 3.28 & 0.84 \\
\hline BEB & $W=0.004 T \min _{\mathrm{FEB}}+0.0003 P_{\mathrm{JUN}}-0.0001 \mathrm{EXC}_{\mathrm{DEC}}+0.093$ & 0.026 & 1.98 & 0.79 & 6.34 & 0.95 \\
\hline LIM & $W=-0.007 T \max _{\mathrm{JAN}}+0.007 T \max _{\mathrm{FEB}}+0.012 T \max _{\mathrm{JUL}}-0.222$ & 0.022 & 1.49 & 0.73 & 3.11 & 0.90 \\
\hline MAT & $W=0.016 T \max _{\mathrm{JUL}}+0.0005 P_{\mathrm{JUL}}+0.001 \mathrm{STO}_{\mathrm{JUN}}-0.396$ & 0.034 & 4.04 & 0.68 & 2.65 & 0.92 \\
\hline \multicolumn{7}{|l|}{ August } \\
\hline BAU & $W=-0.009 \operatorname{Tmax}_{\mathrm{JUL}}-0.010 T \mathrm{max}_{\mathrm{AUG}}-0.0001 P_{\mathrm{OCT}}+0.747$ & 0.010 & 2.07 & 0.94 & 2.02 & 0.87 \\
\hline BEB & $W=-0.012 \operatorname{Tmax}_{\mathrm{APR}}+0.001 P_{\mathrm{JUN}}-0.001 \mathrm{STO}_{\mathrm{OCT}}+0.545$ & 0.025 & 2.52 & 0.79 & 5.28 & 0.97 \\
\hline LIM & $W=-0.024 T_{\mathrm{APR}}+0.009 T \min _{\mathrm{OCT}}-0.011 T \max _{\mathrm{JAN}}+0.931$ & 0.029 & 2.49 & 0.70 & 4.76 & 0.83 \\
\hline MAT & $W=-0.007 T \mathrm{~min}_{\mathrm{MAY}}+0.0004 P_{\mathrm{JUN}}+0.0001 P_{\mathrm{NOV}}+0.188$ & 0.046 & 4.03 & 0.64 & 3.53 & 0.80 \\
\hline \multicolumn{7}{|c|}{ September } \\
\hline BAU & $\mathrm{W}=0.015 . \mathrm{T}_{\mathrm{APR}}+0.007 . \mathrm{T}_{\mathrm{SEP}}-0.0001 . \mathrm{P}_{\mathrm{DEC}}-0.285$ & 0.002 & 1.03 & 0.98 & 2.25 & 0.88 \\
\hline BEB & $\mathrm{W}=-0.003 . \mathrm{Tmax}_{\mathrm{AUG}}+0.0004 . \mathrm{P}_{\mathrm{JUN}}-0.0002 . \mathrm{STO}_{\mathrm{OCT}}+0.237$ & 0.028 & 1.23 & 0.78 & 6.45 & 0.88 \\
\hline LIM & $\mathrm{W}=-0.033 . \mathrm{T}_{\mathrm{APR}}+0.012 . \mathrm{Tmin}_{\mathrm{OCT}}-0.012 . \mathrm{Tmax}_{\mathrm{JAN}}+1.185$ & 0.004 & 1.90 & 0.87 & 5.31 & 0.96 \\
\hline MAT & $\mathrm{W}=-0.021 . \mathrm{T}_{\mathrm{APR}}+0.005 . \mathrm{T}_{\mathrm{OCT}}-0.004 . \mathrm{Tmax}_{\mathrm{AUG}}+0.646$ & 0.068 & 4.23 & 0.57 & 9.29 & 0.76 \\
\hline \multicolumn{7}{|l|}{ October } \\
\hline BAU & $\mathrm{W}=0.007 . \mathrm{T}_{\mathrm{OCT}}+0.157 . \mathrm{RET}_{\mathrm{APR}}+0.066 . \mathrm{RET}_{\mathrm{JUL}}-0.186$ & 0.004 & 1.48 & 0.96 & 2.65 & 0.89 \\
\hline BEB & $\mathrm{W}=0.019 . \mathrm{T}_{\mathrm{MAY}}-0.009 . \mathrm{Tmax}_{\mathrm{AUG}}+0.005 . \mathrm{Tmax}_{\mathrm{SET}}-0.107$ & 0.033 & 3.40 & 0.76 & 7.07 & 0.65 \\
\hline LIM & $\mathrm{W}=0.007 . \mathrm{T}_{\mathrm{OCT}}-0.006 . \mathrm{Tmin}_{\mathrm{MAY}}-0.001 . \mathrm{DEF}_{\mathrm{JUN}}+0.061$ & 0.042 & 2.93 & 0.65 & 3.75 & 0.93 \\
\hline MAT & $\mathrm{W}=-0.048 . \mathrm{T}_{\mathrm{APR}}-0.013 . \mathrm{T}_{\mathrm{DEC}}+0.009 . \mathrm{Tmin}_{\mathrm{OCT}}+1.496$ & 0.022 & 6.51 & 0.73 & 16.61 & 0.44 \\
\hline \multicolumn{7}{|c|}{ November } \\
\hline BAU & $\mathrm{W}=-0.011 . \operatorname{Tmax}_{\mathrm{JUL}}-0.008 . \operatorname{Tmax}_{\mathrm{AUG}}-0.0002 . \mathrm{P}_{\mathrm{DEC}}+0.793$ & 0.001 & 0.68 & 0.99 & 2.10 & 0.91 \\
\hline BEB & $\mathrm{W}=0.0002 . \mathrm{EXC}_{\mathrm{MAR}}+0.0007 . \mathrm{STO}_{\mathrm{AUG}}+0.144$ & 0.048 & 3.36 & 0.58 & 9.99 & 0.42 \\
\hline LIM & $\mathrm{W}=-0.018 . \mathrm{T}_{\mathrm{APR}}+0.012 . \mathrm{Tmin}_{\mathrm{OCT}}+0.001 . \mathrm{DEF}_{\mathrm{SEP}}+0.405$ & 0.040 & 3.37 & 0.66 & 6.22 & 0.79 \\
\hline MAT & $\mathrm{W}=-0.034 . \mathrm{T}_{\mathrm{MAY}}+0.012 . \mathrm{Tmin}_{\mathrm{NOV}}-0.012 . \mathrm{Tmax}_{\mathrm{AUG}}+1.108$ & 0.032 & 7.38 & 0.69 & 5.95 & 0.88 \\
\hline \multicolumn{7}{|c|}{ December } \\
\hline BAU & $\mathrm{W}=0.0002 . \mathrm{P}_{\mathrm{MAR}}-0.0002 . \mathrm{P}_{\mathrm{DEC}}+0.087 . \mathrm{RET}_{\mathrm{JUL}}+0.140$ & 0.050 & 5.09 & 0.81 & 4.05 & 0.71 \\
\hline $\mathrm{BEB}$ & $\mathrm{W}=0.001 . \mathrm{P}_{\mathrm{JUN}}+0.0003 \cdot \mathrm{EXC}_{\mathrm{MAR}}-0.0001 . \mathrm{EXC}_{\mathrm{DEC}}+0.153$ & 0.046 & 3.18 & 0.72 & 4.92 & 0.83 \\
\hline LIM & $\mathrm{W}=0.024 . \mathrm{T}_{\mathrm{JAN}}-0.013 . \mathrm{Tmin}_{\mathrm{FEB}}-0.017 . \mathrm{Tmax}_{\mathrm{JUL}}+0.322$ & 0.038 & 4.06 & 0.66 & 7.57 & 0.81 \\
\hline MAT & $\mathrm{W}=-0.043 . \mathrm{T}_{\mathrm{JUL}}-0.007 . \mathrm{Tmin}_{\mathrm{JUN}}+0.042 . \mathrm{Tmax}_{\mathrm{NOV}}-0.349$ & 0.024 & 8.57 & 0.72 & 6.64 & 0.89 \\
\hline
\end{tabular}

. BAU, Bauru; BEB, Bebedouro; LIM, Limeira; MAT, Matão. The independent variables are Tmin, T and Tmax, minimum, mean and maximum air temperature $\left({ }^{\circ} \mathrm{C}\right)$; EXC and DEF, hydric excess and deficit; STO, soil-water storage; P, precipitation (mm) and RET, relative evapotranspiration for the developmental year (year 1). The dependent variable is for the production year (year 2). Calibration and testing used monthly data from 2001-2009 and 2010-2013, respectively 
The most influential variables for $\mathrm{FRBOX}_{\mathrm{APR}}$ were $T$ max and $T$ min for BEB, $T$ during the first semester for LIM and $T$ during the second semester for BAU (Table 8). BEB presented all the developmental year, first and second semesters, with important variables on the forecast of FRBOX of VACR.

The best FRBOX ${ }_{\text {APR }}$ model was for LIM, with a MAPE of $1.29 \%, R^{2}$ adj $=0.97$, and $P=0.023$ at testing. A mean FRBOX of 280.58 would thus have a forecasting error of 3.62. $T$ and $T$ max at bud formation and vegetative dormancy (June and July) were the most influential variables in the FRBOX $_{\text {APR }}$ model in LIM, indicating that VACR yield was dependent on the initial developmental stages of the plant. Paulino et al. (2007) found significant correlations between the number of fruits per plant and $T \max$ and $T$ in April and June for orchards 3-5 years old and in May and July for orchards older than 6 years.

WFRUIT is directly related to FRBOX: fruit size increases as the number of fruits per box decreases. The WFRUIT models (Table 9) were accurate among all regions and months, with a minimum MAPE of $1.48 \%$ for June in BAU and a maximum of $16.61 \%$ for October in MAT. The minimum range was 4 months for LIM. $T$ was the most important variable for LIM and MAT, RET was the most important variable for BAU, and Tmax and Tmin were the most important variables for BEB, all during the first semester of the developmental year.

The best WFRUIT $_{\mathrm{APR}}$ model was for BAU, with a MAPE of $2.52 \%, R^{2}$ adj $=0.95$ and $P=0.002$ at testing. A mean WFRUIT of $0.16 \mathrm{~kg}$ would thus have a forecasting error of $0.004 \mathrm{~kg}$. RET at bud formation and vegetative dormancy (April and July) was the most important variable in the WFRUIT forecasting model for BAU.

The qualitative attributes (Tables 3, 4, 5, 6, 7, 8 and 9) were most influenced by temperature, indicating that this climatic factor was most important to VACR fruit quality for all regions. RET was also important. Transpiration in citrus plants occurs throughout the year and is influenced by rootstock, cultivar, vegetative growth and corresponding phenological phases (Vellame et al. 2012). Paulino et al. (2007) found a positive effect of VACR evapotranspiration on yield during the phases of flowering, fructification and fruit growth.

\subsection{Model forecasting performance}

The forecasts of the monthly agrometeorological models developed in this study performed well. A comparison of independent data for FRBOX and RATIO for all months of 2010 2013 (Fig. 7 and Fig. 8, respectively) has shown that the forecasts were highly precise. The minimum $R^{2}$ adj was 0.80 for FRBOX in LIM and 0.98 for RATIO in MAT.

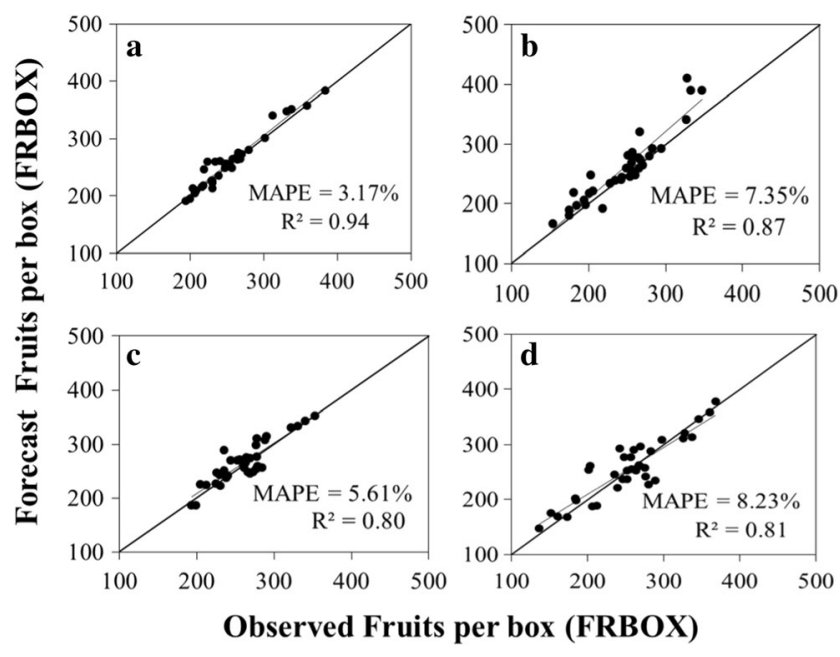

Fig. 7 Accuracy analysis of the monthly models for forecasting FRBOX using independent data from 2010 to 2013. a) Bauru, b) Bebedouro, c) Limeira and d) Matão

\subsection{Overview of climatic parameters during the crop cycle}

We conducted a combined analysis of the four regions to summarize the meteorological variables and their effects on the qualitative attributes of VACR (Fig. 9). The criteria used were the frequency of the variables in the models and the angular coefficients. Tmax was the most important variable during flowering (August) and was positively correlated with BRIX and FRBOX. Tmax in August was negatively correlated with WFRUIT, T in August and February was negatively correlated with RATIO and ACIDITY, respectively. The meteorological variables that influenced \%JUICE and KGSS were in equilibrium during the developmental year, having positive and/or negative correlations with these qualitative variables of VACR.

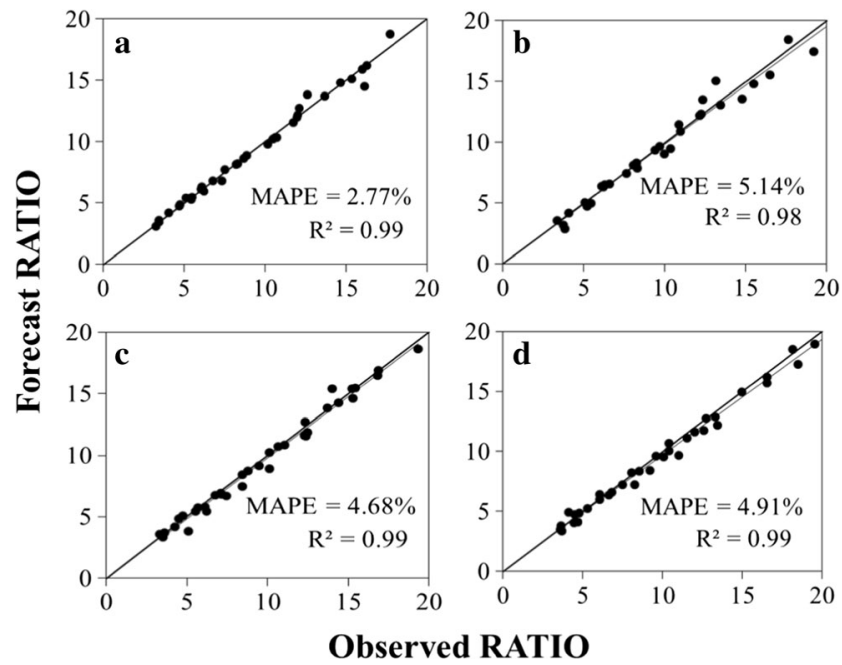

Fig. 8 Accuracy analysis of the monthly models forecasting RATIO using independent data from 2010 to 2013. a) Bauru, b) Bebedouro, c) Limeira and d) Matão 

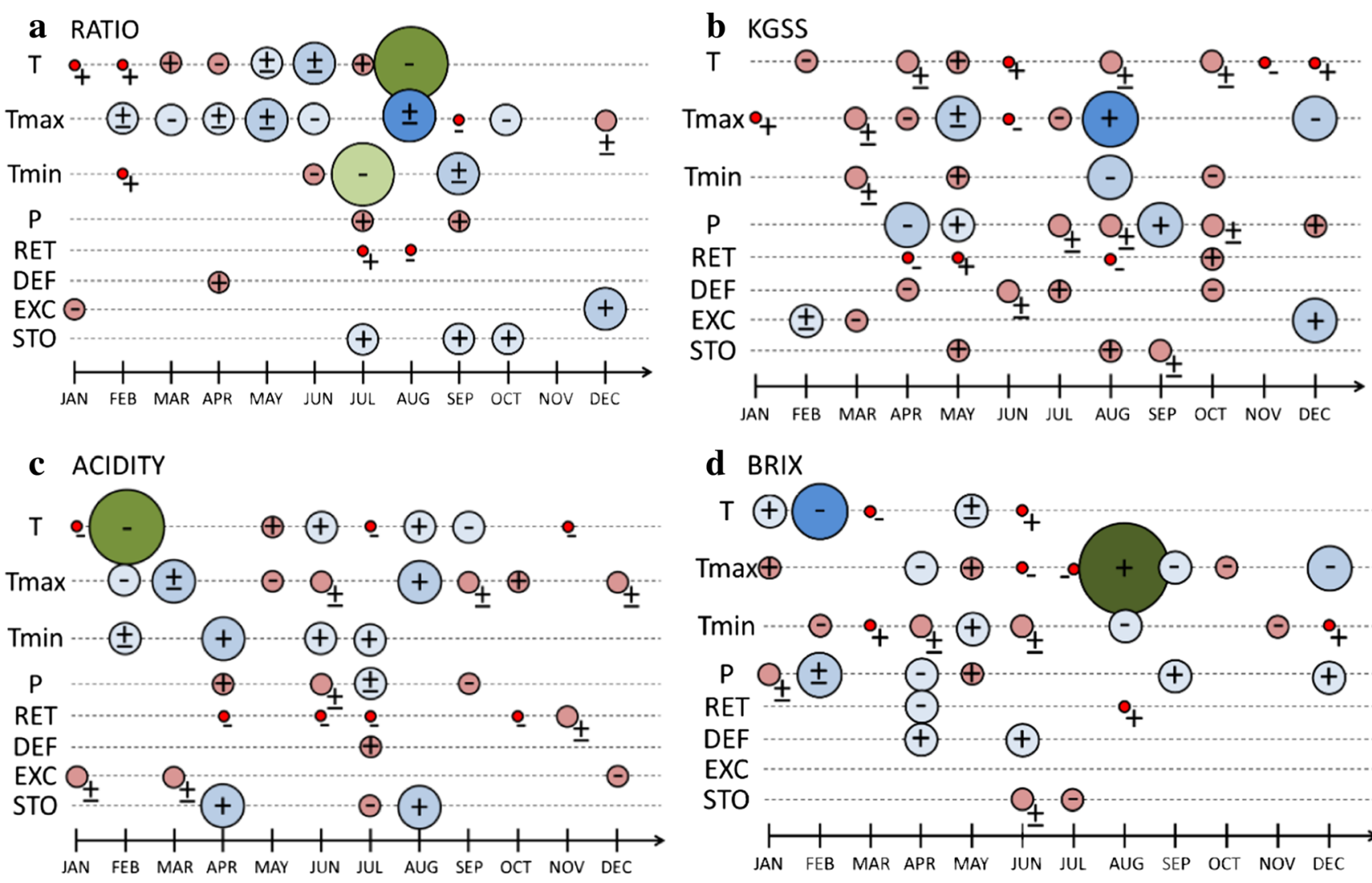

\section{d BRIX}

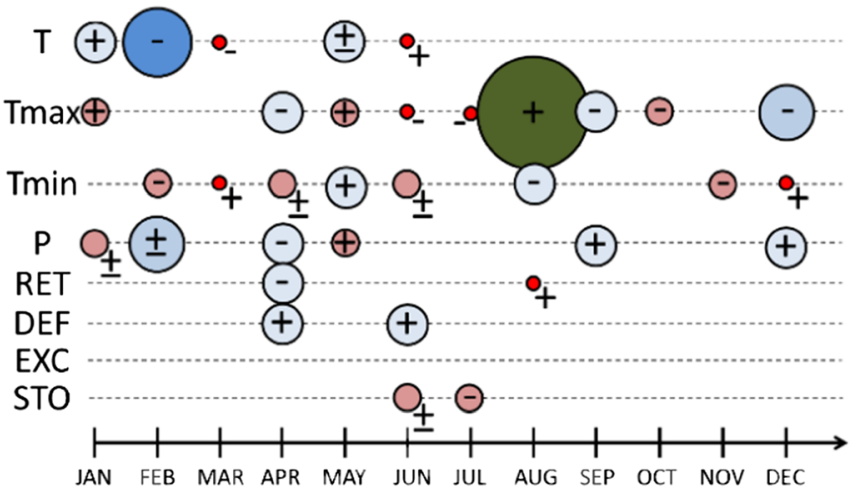

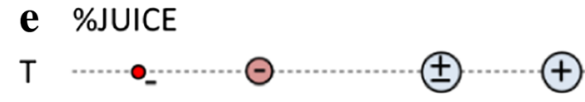

$\operatorname{Tma} \odot \oplus \cdot-\ldots O_{ \pm}-\oplus \oplus \oplus \cdots \cdots$ $\operatorname{Tmin} \odot \quad O$
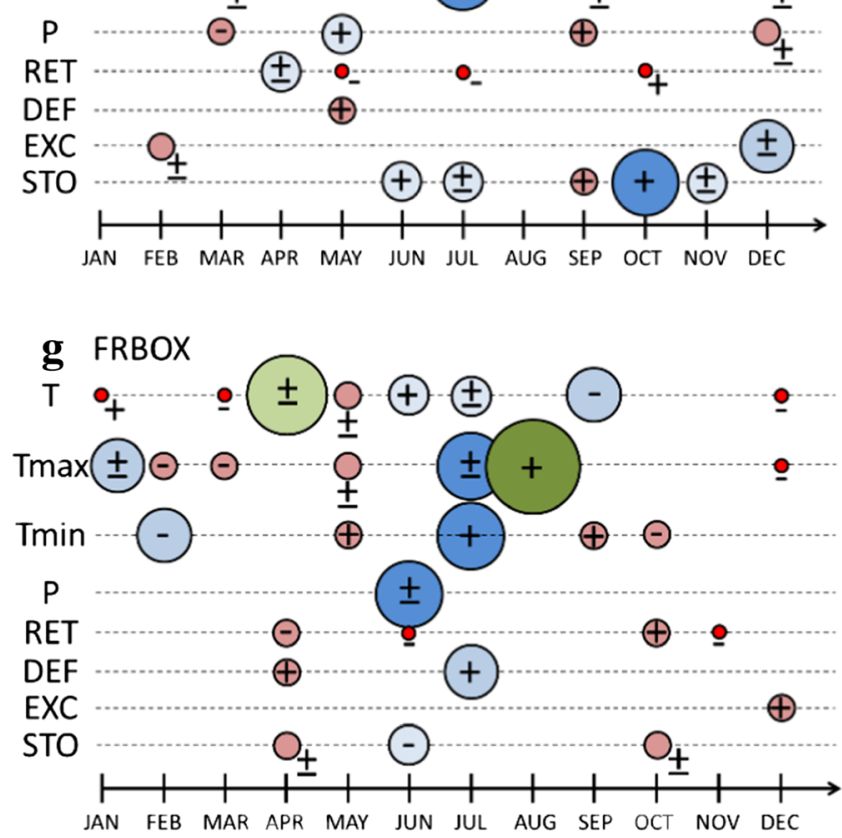

Fig. 9 Overview of the meteorological elements influencing the qualitative attributes of 'Valência' oranges grafted onto 'Rangpur' lime rootstocks in the areas of production in the state of São Paulo. a) RATIO,

\section{f WFRUIT}

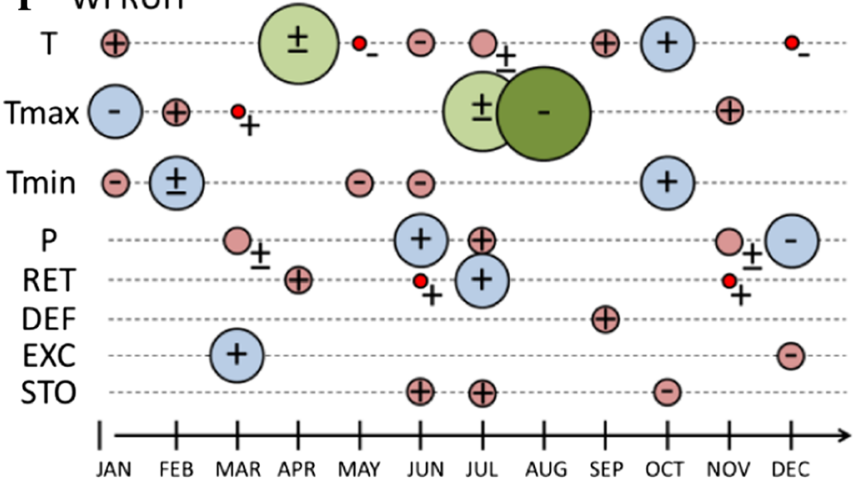

\section{LEGEND}

Frequency (number)

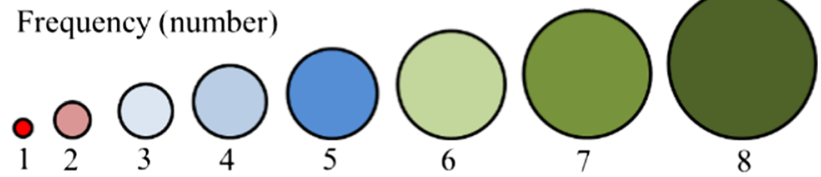

+ Positive correlation

- Negative correlation

\pm Both correlations (Favorable Range)

b) kilograms of soluble solids, c) citric acid, d) sugar content, e) juice percentage, f) fruit weight and $g$ ) number of fruits per box 
DEF was the most important water-balance component for VACR qualitative attributes. DEF at bud formation (April) and vegetative dormancy (July) was most important in the forecast models for BRIX MAY $_{\text {and }}$ FRBOX $_{\mathrm{APR}}$ in MAT and BAU, respectively. DEF did not have a large influence in $\mathrm{BEB}$, with the lowest coefficients in the models that used it. The angular coefficients for FRBOX $\mathrm{JUN}_{\mathrm{N}}$ in LIM indicated that RET was the most influential variable during fruit growth (October), followed by DEF during vegetative dormancy (July).

Paulino et al. (2007) reported similar results and noted that the number of fruits per plant was significantly correlated with DEF in LIM from July to September of the developmental year.

The models were generally accurate for all four regions. The RATIO, KGSS and WFRUIT models were best for BAU, the ACIDITY, \%JUICE and FRBOX models were best for LIM and the BRIX model was best for MAT.

\section{Conclusions}

Testing all possible combinations for selecting the variables and the use of multiple linear regressions were efficient for developing models to forecast the qualitative attributes of 'Valência' oranges grafted onto 'Rangpur' lime rootstocks for four regions in the state of São Paulo in Brazil.

Accurate models as functions of climatic variables were developed for all months. The minimum forecasting ranges were five months for RATIO, four months for FRBOX, BRIX, ACIDITY and WFRUIT and three months for KGSS and \%JUICE for all regions.

Minimum, mean and maximum air temperature and relative evapotranspiration were the most important variables in the models. Water deficit was the most influential waterbalance component on the qualitative attributes of 'Valência' oranges.

Acknowledgments Fisher Group S.A. provided the investment, climatic and 'Valência' orange quality attributes data. We are grateful to Department of Exact Science (UNESP) and the Fisher Group S.A. for the important discussions that helped during this work.

\section{References}

Box GEP, Jenkins GM, Reinsel GC (2008) Time Series Analysis: Forecasting and Control. (4th Edition) 784p. ISBN: 978-0-47027284-8

Cabrera VE, Fraisse CW, Letson D (2006) Impact of climate information on reducing farm risk by optimizing crop insurance strategy. Transac of the ASABE 49(4):1223-1233

Camargo AP (1971) Balanço hídrico no Estado de São Paulo. IAC, Campinas, $28 \mathrm{p}$
Camargo MBP, Ortolani AA, Pedro Junior MJ (1999) Agrometeorological model for yield prediction of Orange cultivar 'Valência'. Bragantia Campinas 58:171-178. doi:10.1590/S0006-87051999000100016

Carmona G, Varela-Ortega C, Bromley J (2013) Suporting decision making under uncertainty: development of a participatory integrated model for water management in the middle Guadiana river basin. Environ Model Softw v 50:144-157. doi:10.1016/j.envsoft.2013.09.007

Castro PRC, Marinho CS, Paiva R (2001) Fisiologia da produção dos citros. Informação Agropecuária 22:26-38

Coelho YS (2002) Frutas cítricas importadas no mercado de Salvador. Bahia Agrícola 5(2):29-33

Confalonieri R, Bellochi G, Tarantola S, Acutis M, Donatelli M, Genovese G (2010) Sensitivity analysis of the rice model WARM in Europe: exploring the effects of different locations, climates and methods of analysis on model sensitivity to crop parameters. Environ Model Softw 25:479-488. doi:10.1016/j.envsoft.2009.10.005

Grizzoto RK, Silva JAA, Miguel FB (2012) Qualidade de frutos de laranjeira Valência cultivada sob sistema tecnificado. Rev Bras de Eng Agríc Amb 16(7):784-789

Gujarati DN, Porter DC (2011) Econometria Básica. In: Basics econometrics (5a Ed.). 872p.

Hammer GL, Carberry P, Stone R (2000) Comparing the value of seasonal climate forecasting systems in managing cropping systems. In: Nicholls N, Mitchell C (eds) Applications of seasonal climate forecasting in agricultural and natural ecosystems the Australian experience, hammer Gl. Kluwer Academic Publishers, Dordrecht, p. 472p

Hansen JW, Potigieter A, Tippett MK (2004) Using a general circulation model to forecast regional wheat yields in Northeast Australia. Agric and Forest Meteor 127:77-92

Kogan F, Kussul N, Adamenko T (2013) Winter yield forecasting in Ukraine based on earth observation, meteorological data and biophysical models. Interna J App Earth Observ and Geoinf 23:192203. doi:10.1016/j.jag.2013.01.002

Matsumura K, Gaitan CF, Sugimoto K (2014) Maize yield forecasting by linear regression and artificial neural network in Jilin. China $J$ of Agric Sci 1:1-12. doi:10.1017/S0021859614000392

Mattheis JP, Fellman JK (1999) Preharvest factors influencing flavor of fresh fruit and vegetables. Postharv Biology and Techn 15:227-232

Moreto VB, Rolim GS (2015) Estimation of annual yield and quality of 'Valência' orange related to monthly water deficiencies. Afr J Agric Res 10(6):543-553. doi:10.5897/AJAR2014.9090

Neves MF (2012) A laranja do campo ao copo. São Paulo Atlas.

Nyamdorj NB, Zerihum A, Gibberd M (2014) Berry composition and climate: responses and empirical models. Intern $\mathrm{J}$ of Biometeor 58 : 1207-1223. doi:10.1007/s00484-013-0715-2

Paulino ES, Mourão Filho FAA, Maia AHN (2007) Agrometeorological models for 'Valência' and 'Hamlin' sweet oranges to estimate the number of fruits per plant. Sci Agric 64(1):1-11. doi:10.1590 /S0103-90162007000100001

Pedro Junior M, Hernandes JL, Blain GC (2014) Curva de maturação e estimativa do teor de sólidos solúveis e acidez total em função de graus-dia: Uva IAC 138-22 'Máximo'. Bragantia. Campinas 73(1): 81-85. doi:10.1590/brag.2014.011

Pio RM, Figueredo JO, Estuchi ES (2005) Variedades Copas. In Mattos Jr D, Negri JD, Pio RM, Pompeu Jr J (Eds). In: Citros. Instituto Agronômico. 929p.

Ribeiro VR, Machado CE, Brunini O (2006) Ocorrência de condições ambientais para indução do florescimento de laranjeiras no estado de São Paulo. Rev Bras de Frutic 28(2):247-253. doi:10.1590/S010029452006000200021

Ruslan R, Ehsani R, Lee WS (2012) Quantification of total soluble solids and turatable acidity for citrus matyrity using portable Vis-NIR spectoradiometer. App Engin in Agric 28(5):735-774. doi: $10.13031 / 2013.42420$

Salvo S, Muñoz C, Ávula J (2012) An estimate of potential blueberry yield using regression models that relate the number of fruits to the 
number of flower buds and to climatic variables. Sci Hortic 133(6): 56-63. doi:10.1016/j.scienta.2011.10.020

Santos RM, Naas IA, Neto MM (2013) An overview on the Brazilian Orange juice production chain. Rev. Bras. de Frutic 35(1):218-255. doi:10.1590/S0100-29452013000100025

Sentelhas, PC (2005) Agrometeorologia dos citros. In: Mattos Junior D, De Negri JD, Pio RM, Pompeu Junior J (Org.). Citros. Campinas: IAC/FUNDAG. p. 319-344.

Thornthwaite CW (1948) An approach towards a rational classification of climate. Geogr Rev 38(1):55-94

Thornthwaite CW, Mather JR (1955) The water balance. Publications in Climatology 1:104

Uribe-Bustamante A, Curti-Diaz AS, Hernández-Guerra C (2013) Calidad de naranja 'Valência' injertada em 20 portainjertos. Rev Chapingo Serie Hortic 19(1):61-69. doi:10.5154/r.rchsh.2011.08.043
Vellame LM, Coelho RD, Tolentino JB (2012) Transpiração de plantas jovens de laranjeira 'Valência' sob pota-enxerto limão 'Cravo' e citrumelo 'Swingle' em dois tipos de solo. Rev. Bras. de Frutic 34(1):24-32

Volpe CA, Schoffel ER, Barbosa JC (2002) Influência da soma térmica e da chuva durante o desenvolvimento de laranjas 'Valência' e 'Natal' na relação entre sólidos solúveis e acidez e no índice tecnológico do suco. Rev. Bras. de Frutic 24(2):436-441. doi:10.1590/S01002945200200020003

Walpole RE, Myers RH, Myers SL (2012) Probability \& statistics for engineers \& scientists. (9th Edition). 791p, 2012. ISBN: 978-0321-62911-1

$\mathrm{Xu}$ L, Zhang WJ (2001) Comparison of different methods for variable selection. Analyt Chim Acta 446:477-483 